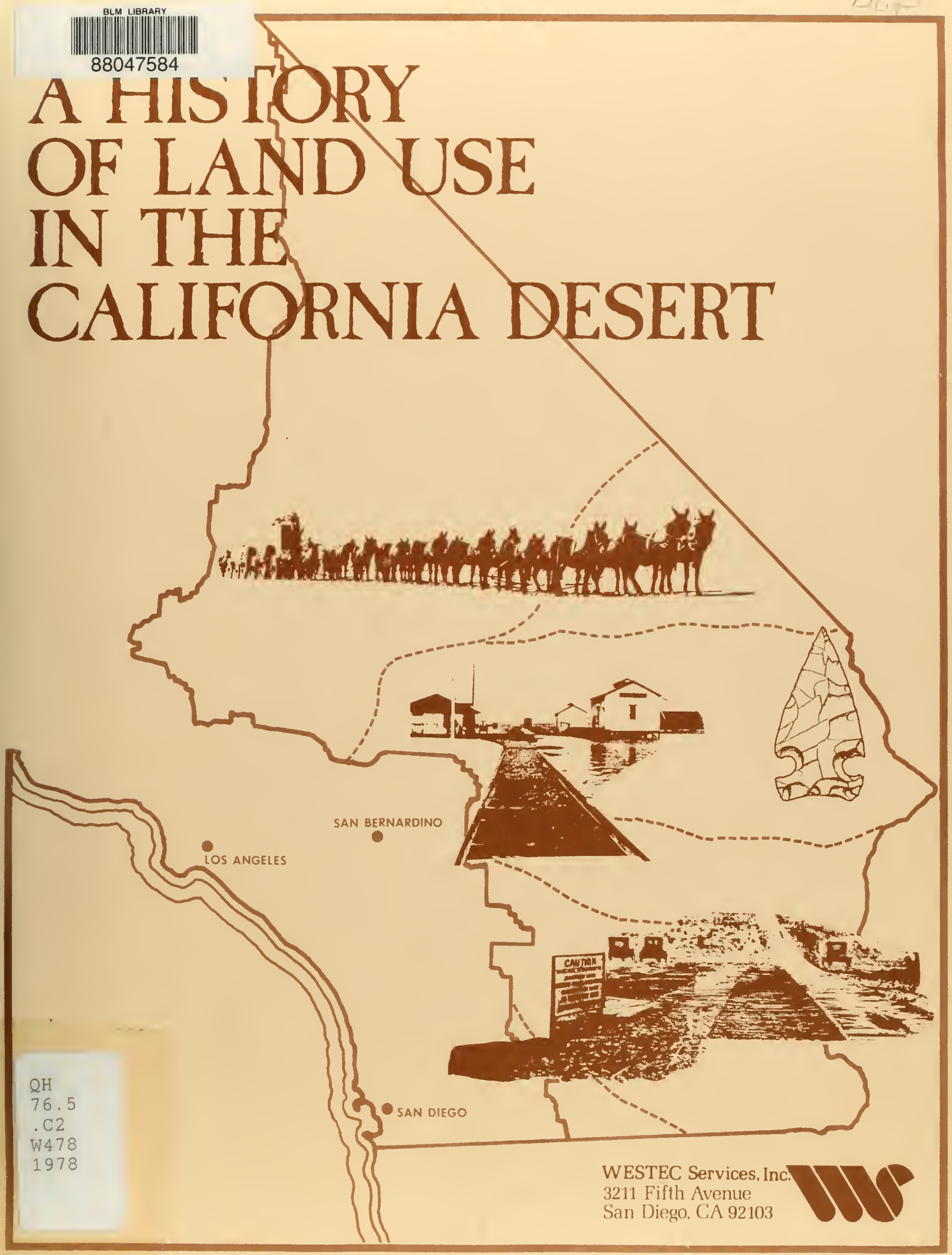






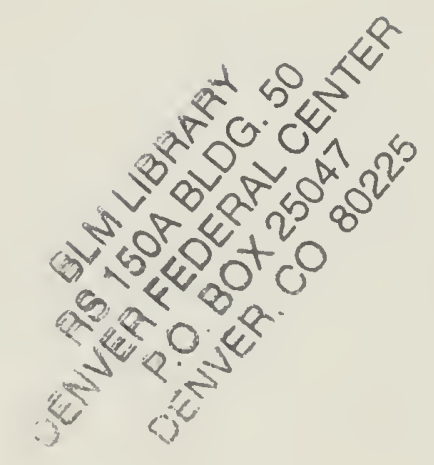




\title{
A HISTORY OF LAND USE IN THE CALIFORNIA DESERT CONSERVATION AREA
}

CONTRACT NO. YA-512-RFP7-140

\begin{abstract}
PREPARED FOR :
DESERT PLANNING STAFF

BUREAU OF LAND MANAGEMENT

$U, S$, DEPARTMENT OF THE INTERIOR

3610 CENTRAL AVENUE, SUITE 402

RIVERSIDE, CALIFORNIA 92506
\end{abstract}

\author{
PREPARED BY : \\ WESTEC SERVICES, INC, \\ 3211 FIFTH AVENUE \\ SAN DIEGO, CALIFORNIA 92103
}

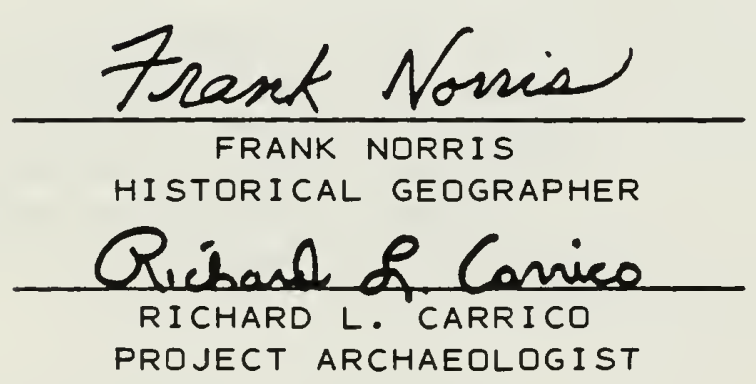

AUGUST 1978

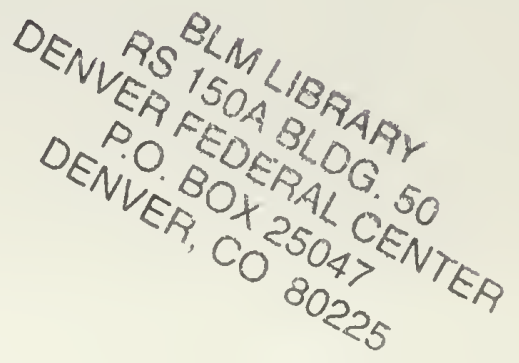



Summary

Preface

Pre-Contact Native American

Knowledge and Use of the Land

The 1540-1846 Period:

Spanish and American Exploration and the Opening of the Desert

The 1846-1868 Period:

Americans in the Desert;

Exploration, Railroad Surveys

and Military Activity

4

The 1868-1885 Period:

Initial Mining and

Railroad Impacts Occur

The 1885-1895 Period:

Mining Production Continues

While Homesteading Develops,

Particularly in the

Antelope Valley

6

The 1895-1907 Period:

Agriculture Booms in the California Desert; Mining Discoveries Spread to New Areas as New Railroads Make Ore Sites Accessible

The 1907-1917 Period:

Mining Impacts Continue

While Homesteading Develops 
TABLE OF CONTENTS (Continued)

Chapter

Title

$\underline{\text { Page }}$

8

The 1917-1925 Period:

Highway Settlements Develop;

Homesteading and Other

Activities Slowly Decline

The 1925-1932 Period:

Highway Settlements Develop, While the Amenities Gain More

Importance as a Desert

Attraction

The 1932-1940 Period:

Government Work Projects and a Mining Revival Impact the

Desert; Parklands Appear

The 1940-1945 Period:

The Military Impacts the Land;

The Desert is Further Classified,

While Some New Mining Impacts Occur

The 1945-1951 Period:

Residential Boom.on the Metropolitan

Fringe; Larger Towns and Intensive Agriculture Grow While More Small-

Scale Activities Decline

The 1951-1960 Period:

Postwar Growth Trends Continue;

Recreational Use of the Desert

Becomes More Noticeable

The 1960-1978 Period:

Continuation of Growth on the Metropolitan Fringe; Freeways Proliferate; Off-Road Vehicle Use Becomes Widespread; Designated Wilderness Areas Appear 
TABLE OF CONTENTS (Continued)

$\underline{\text { Title }}$

$\underline{\text { Page }}$

Epilogue:

Projections for the Future

Appendix

A - 1

References Cited

$\mathrm{R}-1$

\section{LIST OF FIGURES}

Figure

$\underline{\text { Title }}$

$\underline{\text { Page }}$

1

Linguistic Groupings, Native

American Territories and

Lithic Sources In and Around

the Study Area

2

Approximate Locations of

Unratified Treaty Land

(1851-1852) In and Around

the Study Area

3

Major New Dry-Farming Areas,

California Desert Conservation Area, 1900-1925

4

Annual Visitation to Selected

Parks and Monuments, California

Desert Conservation Area

90 
SUMMARY

The history of the California desert, as a rule, has been one of continually increasing land use intensity. With the exception of mining, agriculture and grazing, all sectors of the economy have generally grown more complex with the passage of time. Due largely to the population growth in more coastal portions of southern California, growth in desert areas has been particularly rapid since World War II. However, there are still many significantlysized areas which have received very little, if any, alteration in land use in historic times.

Prior to the arrival of the first exploring parties in the mid-16th century, native Americans had little effect upon the 1 and. Native foraging and hunting required only insignificant alteration of natural vegetation and landform. Farming, where practiced, was accomplished by using natural flooding for irrigation, although springs and water sources were sometimes expanded or improved by wells. Well-worn, although unimproved, trails served as transportation routes throughout the desert. In brief, native land use was of a more passive, and therefore less altering, nature than the land use of later peoples.

Although several traverses of the desert were made by Spanish, Mexican and American groups from 1771-1850, non-native land use impacts were non-existent aside from grazing, some intermittent small-scale salt extraction, and minor attempts at improvement of water sources. 
After the desert came under the jurisdiction of the United States, minor impacts began to occur. Grazing was one of the first industries to grow; by the $1870 \mathrm{~s}$, large cattle ranches had established themselves over most of the more well-watered areas. They continued to grow in importance until around 1900 , when due to overgrazing, cattle usage began to stabilize.

Mining also became important in the pre-railroad period, first in districts along the more well-traveled routes, and later in scattered, remote areas. Many of the early miners were Mexican immigrants; discoveries at Picacho, Cerro Gordo and the E1 Paso Mountains testify to their presence.

As coastal southern California grew in popularity, various roads were established. The Southern (Butterfield) route, dating from 1846, and the 01d Spanish Trail, dating from 1830, were the earliest major routes; these were augmented by the old Government Road-Mohave Road in about 1860, and the Bradshaw Trail (new Government Road) in 1862. Each road system had a few way-stations scattered along its route.

In the late $1870 \mathrm{~s}$ and $1880 \mathrm{~s}$, the importance of trails was diminished considerably by the coming of the railroad. Railroads made all desert points more accessible, and created population clusters of their own. In general, the presence of the railroad did not greatly improve the fortunes of the various mining camps. Scattered first over the northern desert, and later in many desert areas, mining camps continued to proliferate through the $1880 \mathrm{~s}$, $1890 \mathrm{~s}$ and 1900s. Major ore sites were located at Calico, Randsburg, Stedman, Hedges, Providence and Dale. Many new camps of the 
1900 s were in the northern deserts. With few exceptions, the camps lasted less than a decade; by World War I, the heyday of precious mining had essentially elapsed. Since that time, mining development has continued strong, with a few large corporations extracting soda ash, gypsum, salt, borax and other materials. This has been augmented, however, by some subsistence mining during the Great Depression, and small-scale precious mining, primarily for recreational value, continues to the present day.

With the chaotic growth and development of the many early mining districts came a series of mining railroads connecting the major transcontinental lines, principally the Santa Fe route. Spur lines reached to Stedman, Barnwell and Randsburg, and an entire new north-south line was constructed to supply the Death Valley and adjacent Nevada mining areas. Lines from Mojave to Lone Pine and the Salt Lake route northeast of Barstow completed the railroad framework by 1915 before abandonments began.

Homesteading appeared in the Antelope Valley in the 1880 s, and by 1910 had spread to many of the higher-elevation basins. Few were successful, however, due primarily (although not exclusively) to lack of water. Agricultural development in Imperial Valley and in various areas along the Colorado River, however, was not comparable due to water availability. Imperial Valley was opened in 1901 with water from the Colorado; although a major flood wreaked havoc on the area in 1905-07, growth of the Valley continued until 1925, when the area became almost as fully planted as today's acreage. Canal development brought similar growth to the Blythe and Bard 
areas by World War I, but the Coachella Valley saw only limited development until after the Second World War.

Large-scale aqueduct projects brought periodic booms to the desert. The Owens Valley Project of 1907-13, the Metropolitan Water District Project of 1934-41, and the All American/Coachella Canal Projects of 1934-48 are the major impacts, although the recent California Water Project and various canals within agricultural areas have also been built. The road system of today is largely a hybrid feature; auto routes began in the prewar period as graded trails along railroad tracks, and the major routes were paved between 1925 and 1935. Connecting roads were built and paved after World War II, while most of the desert Interstate System was constructed between 1960 and 1972 .

The desert's designated open spaces -- national monuments and state parks - - were primarily designated in the 1930s, although several smaller parks have been created since 1950. Military areas began to be set aside in the 1930s; they exploded into the dominant desert land use in World War II with General Patton's armored-division exercises and many other bases and stations, and have continued to be a major component of desert land use during the postwar period.

Postwar years have seen new levels of interest in the desert, as the desert's population, which had always been increasing at a fairly rapid pace, doubled its previous growth rate. Many large towns appeared which had once been quite minor, and other towns were created where none had existed before. Population pressure, 
from local areas but especially from the Los Angeles and San Diego areas, has had detrimental effects, primarily in off-road vehicle impact areas. Accordingly, the BLM has had to categorize certain areas for their use, while other areas have been designated for wilderness values. 


\section{PREFACE}

This report, Historical Land Use Study of the California Desert, has been written in accordance with Contract No. YA-512RFP7-140. It is intended for use by both Bureau of Land Management planners and interested citizens; its goal is to provide a single, brief overview of the historical land use development that has occurred in the California Desert Conservation Area in historic and recent aboriginal periods. Because of the terms set forth in the contract, the history presented must, by necessity, be generalized in its content, though specific examples of land use development in a particular area have been provided where possible when they appeared representative of similar situations in other areas. For similar reasons, the text material by necessity has had to be limited; however, the various maps that have been prepared have allowed a slightly greater degree of detail, particularly in regard to mining districts. Additional notes of interest have been added to the maps where space permits.

A note is in order regarding source materials. The information included here has been distilled from a representative sample of the local histories, magazine articles and other secondary materials available, and various governmental bureaus, private companies and individual experts have also contributed. However, the historical progression given here is by no means thorough, and the person who wishes to uncover more detailed data should consult any of several libraries or historical societies for this purpose. 
Cultural resource overviews have been written for the BLM for some desert areas, and others will soon be completed. The bibliography to this volume may also prove to be of some help.

The historical development described has been aligned on a strictly chronological basis, using dates which appear to be most important in signifying changes in land use patterns. It is realized that historic periods can never conveniently fit into such rigid, non-overlapping classifications; therefore, generalizations are made from adjacent periods when growth or decline of specific land use occurs over an extended period.

Accompanying this text are a series of maps of the California desert, prepared at a scale of 1:500,000 (about eight miles to the inch). The maps, like the text, chronicle the land-use development of the study area and are designed to correspond with the various chapters in the text. However, direct references to the maps have not been made in the text. Because most readers will not have access to the maps, every effort has been made to keep place names general enough to allow the reader to follow the text by use of any good-quality California map.

A few points of definition should be made here. While it is realized that, strictly speaking, there are several other areas of California desert land than those included in the California Desert Conservation Area, the terms "California desert," "the CDCA" and "the study area" will be used interchangeably for the purposes of this report. "Native Americans" refers to the native peoples of California prior to European contact and will be used 
interchangeably with "native." Although the term "native American" can be considered synonymous with "Indian," we prefer to avoid further use of the term "Indian." 
$x i v$ 
CHAPTER 1. PRE-CONTACT NATIVE AMERICAN

KNOWLEDGE AND USE OF THE LAND.

At the time of significant European contact and intrusion, circa 1771, the California Desert Conservation Area (CDCA) was occupied by fourteen major native groups: the Mono, the Kawaiisu, the Koso, the Tubatulabal, the Ute-Chemehuevi, the Serrano, the Vanyume, the Cahuilla, the Kitanemuk, the Kamia, the Kumeyaay (Southern Diegueño), the Yuma, the Halchidhoma and the Mohave. The boundaries shown in Figure 1 represent the approximate territories at time of contact. ${ }^{1}$ Because native American land use and concept of territory were not as specific nor politically based as were European systems, these boundaries are at best graphic aids rather than clear territorial markers. Additionally, it should be understood that between the time of initial European contact and the establishment of reservations, the territories were in a state of flux because of warfare between the Mohave, Yuma, Halchidhoma and Pima/Maricopa. ${ }^{2}$

Native American land use in the study area can generally be classified into six major categories: (1) major village sites or rancherias; (2) temporary seasonal campsites or special activity areas; (3) trails; (4) quarries and mines; (5) farming areas; and finally, (6) landmarks, sacred complexes or points of interest. Some of these land uses are not mutually exclusive; for instance, a village site may have been chosen because of its proximity to quarries, fertile land and water. 


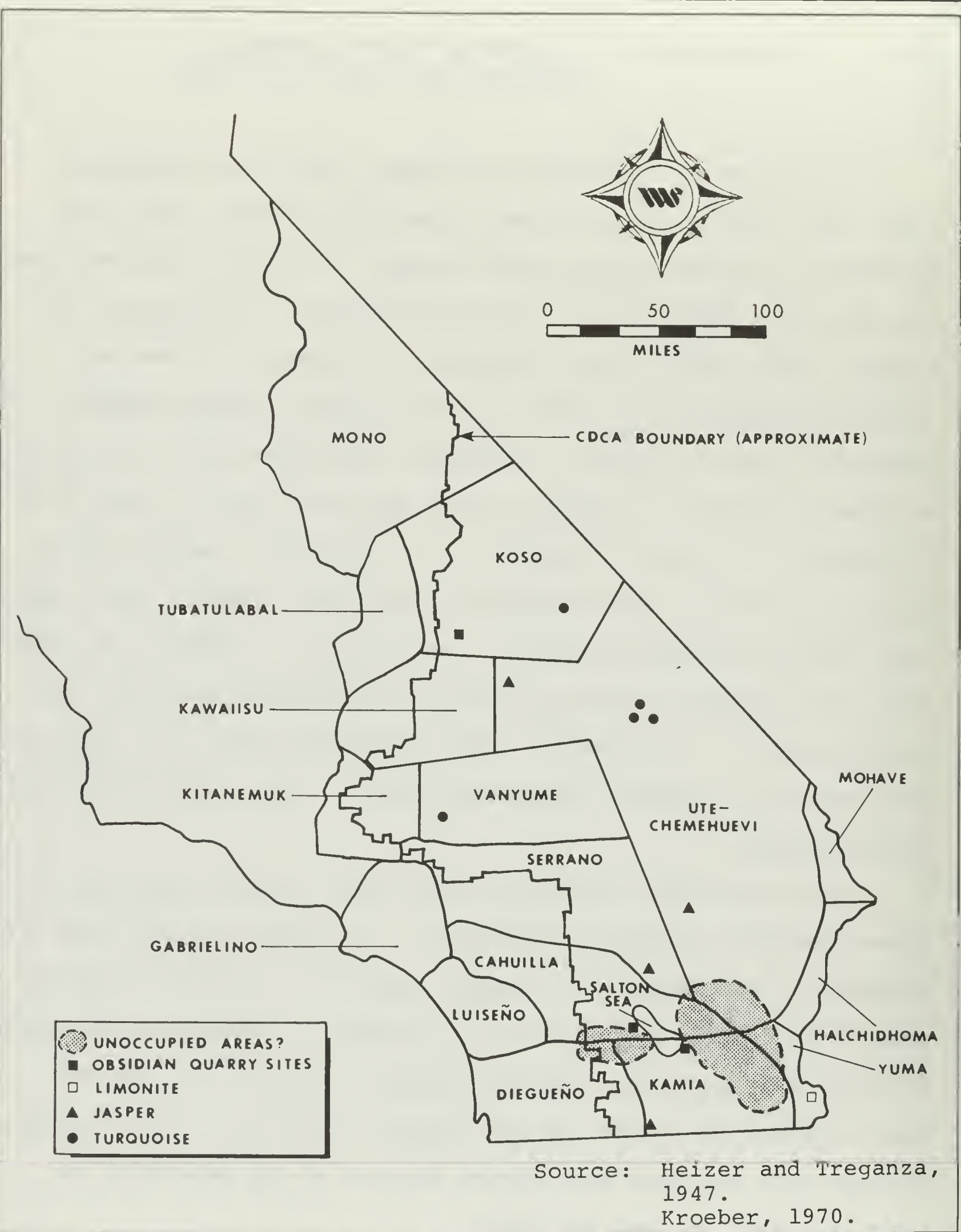

Linguistic Groupings, Native American Territories and FIGURE Lithic Sources In and Around the Study Area. 
The degree to which native American activities within the study area would have affected or impacted the land is a function of duration and intensity of the activity. Kamia irrigation and farming near the Colorado River and the lower Salton Sea basin did not involve the drastic land alteration required by nineteenth and twentieth century Anglo-American farming. ${ }^{3}$ Similarly, pre-contact Chemehuevi and Koso quarrying activities were done without metal tools or western technology, thus avoiding the later effects that large scale mining caused. ${ }^{4}$ However, one should not view the native Americans who lived within the study area as passive occupants nor as noble savages who lived in perfect harmony with nature and left the land unmarked; as discussed briefly below, such was not the case.

Native American village sites or major campsites dot the landscape throughout the CDCA, with a concentration adjacent to the western foothills and along major water courses. It is not within the scope of this analysis to document even a small portion of the known native village sites, although it will be instructive to outline the location, size and impact of a few major native settlements.

Ethnographic and ethnohistoric data on several villages throughout the study area indicate that they were generally seasonal settlements that were occupied during the winter and spring months. During the summer and fall months the majority of the populace, although not the entire village, dispersed, broke into small units (clans or families) and exploited the areas beyond 
their rancheria bases. Although populations varied greatly from village to village, a settlement containing 50 to 80 individuals was average, while a population of over 200 was extremely high.

In most cases the impact of a native settlement upon the surrounding land was minimal and ephemeral as witnessed by the inability of many recent researchers to accurately locate ethnohistorically known villages. Construction of relatively small brush huts, excavation of wells (where possible) and overall maintenance of a village complex required little landform alteration or construction of lasting features. In some areas, however, burning was performed to flush out wildlife, ${ }^{5}$ while along perennial streams flood irrigation was often practiced. 6

Native American impacts upon the land were perhaps most pronounced in and around Cahuilla rancherias at Palm Springs (Kauwis), Indio (Pal-te-wat), and the present-day Torres-Martinez area. ${ }^{7}$ The earliest historical accounts of these settlements noted the extensive agricultural lands, the large, carefully maintained wells (at Toro, for example) and relatively dense occupation. ${ }^{8}$

Native mining activities predate European contact as evidenced by the presence of exotic lithic materials in prehistoric midden deposits. The mines and quarries shown in Figure 1 represent only a small portion of the probably hundreds of such exploitive areas within the study area.

Exotic stones such as obsidian were quarried from Obsidian Butte within Kamia territory, Travertine Point in the Cahuilla sphere of influence, and near Coso Hot Springs in the southern 
segment of Koso territory. ${ }^{9}$ Jasper quarries were located in UteChemehuevi territory near Sheephole Mountain and near Baker; in Serrano/Cahuilla territory near the Mecca Hills and in the Pinto Wash/Dos Cabezas area within Kamia territory. A major source of limonite is situated near Picacho Peak in traditional Yuma territory.

Native American mining and quarrying at the above locations, and for most locations throughout the study area, consisted primarily of shallow pits and exploitation of surface gravels and float. By contrast, turquoise mines in San Bernardino County north of Baker were extensively worked in large open pits often extending as deep as twelve feet; ${ }^{10}$ other turquoise was mined by the Vanyumes near Oro Grande. ${ }^{11}$ It is of special interest that these rich turquoise veins in Ute-Chemehuevi territory were worked by stonesmiths from the Arizona region, thus implying a regularized travel route between the Southwest and these distant resources. ${ }^{12}$ Native American trails across the land comprise one of the most enduring effects and evidence of native land use, although they are often indistinguishable from game trails. Several of the major trails are documented in native American travel songs and dream songs, by ethnographic data and historical/ethnohistoric documents. The hundreds of small, and perhaps shorter, subsidiary trails are not shown nor are they well-documented, except in archaeological field notes and site forms.

The routes depicted in Map 1 and generally described below should be perceived as a corridor rather than as a specific route. 
Individual travellers might vary their route because of personal endurance, $1 \mathrm{ack}$ or presence of water, nature of goods being transported, i.e. driving horses across the desert might require a different route than individual runners would need, and tangential stops made for the purpose of trading.

The Mohave Trail, spanning the 270 miles (420 kilometers) between Needles and Mission San Gabriel, is perhaps the most significant native transportation route across the study area. Colorado River natives, including the Mohave, used the Mohave Trail in pre-contact times as a trade route across Chemehuevi territory to the coastal plains and foothills of southern California. The extensive trading network of the Mohave allowed them to receive rabbit-skin blankets from the Paiute in southern Nevada; eagle down and chicken hawk down from the Chemehuevi; shell and steatite from the distant coastal Chumash; and baskets from various other groups. ${ }^{13}$ In return, the Mohave supplied gourds, beadwork, pottery and probably other goods. ${ }^{14}$ After the introduction of the horse in the 16 th century, the Mohaves became noted for their ability and daring as horse traders and horse thieves, often driving the horses across the Mohave Trail to eager native American consumers. As discussed later, major portions of the original Mohave Trail later became the Government Road/Mohave Road.

The Cocomaricopa Trail constituted the second major native system across the CDCA. The antiquity of this trail is not as well-documented as that of the Mohave Trail, although most scholars agree that the Cocomaricopa Trail was a significant trade and travel route prior to its use during the early Spanish period. ${ }^{15}$ 
Beginning east of Blythe, the Cocomaricopa Trail travelled in a west/northwest direction paralleling Highway 10 below Chuckwalla Valley, south to the Mecca Hills and then sharply northwest through Indio, up the Coachella valley to white water and then west into the coastal plain. Trade goods from the Yuma and Mohave, including gourd rattles and tobacco, were brought across the trail and traded at the several villages situated at Blythe, Mecca, Indio, Indian Wells, Palm Springs, White Water, and Cabazon.

A third major native trail system, the Yuma-Needles Trail, originated southeast of Yuma and travelled northwest between Picacho Peak and the Chocolate Mountains. From this point, the route crossed the eastern border of California staying on the western side of the Colorado River. Near Needles the trail crossed the Mohave Trail, thus marking a major junction of native American trail systems. 16

This route linked together the large Yuma settlements near Yuma with the Yuma/Halchidhoma villages near Blythe and with Mohave rancherias in and around Needles. Gourds and eagle feathers travelled south from the Mohave to the Yuma, and tobacco was traded north by the Yuma. ${ }^{17}$ The route also served as a major raiding trail for Mohave warriors in their attacks along the Colorado River. Francisco Garcés probably followed the general course of the Yuma-Needles Trail during his 1776 trek up the western bank of the Colorado River, as discussed later. ${ }^{18}$

As documented in Chemehuevi myths and journey songs, several well-known trails travelled north-south along the boundary between 
the Chemehuevi and their Mohave/Halchidhoma neighbors. ${ }^{19}$ During times of peace the Chemehuevi also used the Needles-Yuma Trail to travel up and down the river's edge. However, sporadic warfare with the Mohave, and between the Mohave and the other Colorado River peoples, resulted in the closure of the riverine route, and increased Chemehuevi traffic on the more easterly route between Needles and the Chuckwalla Valley.

The extreme southern portion of the study area was traversed by an east-west trail system that originated east of Picacho Peak. This Picacho-San Diego Trail was a major transportation route linking the Yuma, Kamia, Kumeyaay and Northern Diegueño together. 20 Near Harper's Well the Picacho-San Diego Trail intersected with another trail system that travelled north-south along the western edge of the Salton Sea linking Kamia and Cahuilla peoples. From Harper's Well the Picacho-San Diego route dipped southwest around the Fish Creek Mountains, traversed Vallecitos and San Felipe creeks and left the CDCA in the foothills of the Laguna Mountains.

The Picacho-San Diego Trail was used by Yuma raiders on their frequent forays into San Diego County. Its main purpose, however, was as a well-travelled trade route. The Kumeyaay supplied acorns to the Mohave, tobacco, baskets, eagle feathers, acorns and yucca fiber to the Kamia, acorns to the Yuma and eagle feathers to the Cocopa. In return, the Kumeyay received salt from the Cocopa, gourd seeds from the Mohave, salt and vegetal foods from the Kamia, gourd seeds from the Yuma and a large variety of food stuffs from non-specific sources in the desert. 21 
As was the case with many of the trails throughout California, small sections of the Picacho-San Diego Trail were used for local traffic. The Kumeyaay inhabitants of a large summer camp in the Mount Laguna area of San Diego County made yearly treks down this trail, or one of its spurs, on their way to their winter village at Vallecitos (or Met-nook). 22

One of the longest and most extensive trail systems in California leads south out of Owens Valley on its way to the Mohave/ Tehachapi Pass area. North of Owens Valley this route continues to a point beyond the Oregon-California border. Within the CDCA, the route skirts the Sequoia Mountains travelling along the present route of Highways 14 and 395 . Specific data about this route are vague because of its late discovery by Europeans and thus a lack of ethnohistoric information. However, ethnographic data indicate that salt, obsidian, deerskins and a large variety of seeds were transported over this route by Koso, Ute-Chemehuevi and Serrano traders. 23

Other shorter but no less significant trails include the trail system previously mentioned as traversing the western shore of the Salton Sea. This route skirted the San Bernardino Mountains and linked together large rancherias at White Water, Palm Springs, Indian Wells and Torres Martinez. At its northern terminus near White Water, this route intersected with the Cocomaricopa Trail. The Cahuilla used this trail to travel through Kamia territory and make contact with the Yuma. The Yuma provided the Cahuilla with gourd rattles. Red pigments were also traded in from the east. 
Sea shells from the Gulf of California were brought up this trail by Cocopa traders.

Hundreds, if not thousands, of spur or adjunct trails spun off from the major routes noted above, forming a web of well-trod paths across the study area and well beyond. Many of the major trails later became European and American transportation routes, as discussed later, while others continued to be used by native Americans well into the twentieth century. Today the remnants of these early routes can often be seen etched into the desert landscape. Artifacts and trail shrines often mark routes of these highways of the past.

Features and landforms often possessed significance to native American groups and are indicative of native American land use or knowledge of the landscape. Picacho Peak was a landmark and sacred area to the Kumeyaay; ${ }^{24}$ the pinnacle formations at Needles are mentioned in Chemehuevi hunting songs; the Whipple Mountains are important Chemehuevi mythological origin points; and Dead Mountain (near Needles) was a sacred peak (Avikwame) to the Mohave, Yuma and Kumeyaay. 25 Piute Spring was a ceremonial center for the Chemehuevi ( $P a^{\prime} a s h$ ) and the Mohave (Ahakuvizya), as witnessed by the numerous pictographs located there. 26 Black Mountain, located in the El Paso Mountains, was the reported site of sacred ceremonies for natives from as far away as Utah and Colorado. 27

Significant landmarks or ceremonial/sacred areas beyond the CDCA abound; those of importance to this study include Mount San Jacinto in San Bernardino County, a mythological dwelling place for a Kumeyaay diety, Chaup. 28 Further removed is Eldorado Canyon 
along the Colorado River in Nevada. This canyon (Aha'av'uzypo) has religious significance to the Mohave and to the Yuma. 29 Charleston Peak (Nuvant), also in Nevada, was also of significance to the Chemehuevi. 30

Native American placenames dot the CDCA landscape, including such native-derived words as: Panamint; Ubehebe; Tucki (sheep); Ivanpah, derived from ?Avimpah or ?Aavimpah (White Clay Water); Yuma; Koso; Piute (Paiute); Shoshone, from tso-so'ni; Mojave; Chemehuevi; Coachella or Cahuilla or Coahuila; Yuha; and Inyo. 31 Many of the non-European placenames of the area reflect native American cognates or derivations. The prefix ha or ja is significant (as in Jacumba) because it denotes the Yuman word for water. Numerous American or Spanish words denoting places named after native American groups or otherwise indicating their past presence include Indian Wells, Indio (Spanish for Indian), and Degeynous/ Diegueño.

In summary, the pre-contact land use pattern of native Americans within the CDCA was primarily one of seasonal occupation and sporadic flood farming (especially near the lower Salton Sea, the Colorado River and near Palm Springs). Mining and quarrying activities, while often extensive, were limited in their effect upon the landscape. Major and minor transportation arteries crisscrossed the study area, revealing an elaborate native trade network and indicating the seasonal movement of people in their quest for food and materials. Small-scale well excavations were conducted to improve upon, or widen, existing natural wells, particularly in Coachella Valley. 
Landmarks, ceremonial features and points of interest throughout the CDCA appear frequently in the songs, myths and oral tradition of the various native Americans who inhabited the region. Mythological and everyday descriptions of distant water sources, landforms and human occupants as revealed by these same songs and stories clearly indicate an awareness and knowledge of distant environs. 


\section{CHAPTER 1 FOOTNOTES}

1. Kroeber $1970: \mathrm{Plate} 57$

2. Spier 1933

Ezell and Ezell 1970:168-173

Kroeber 1970:797

Forde 1931:103

Aschmann n.d.:248

3. Kroeber 1970

Gifford 1931

4. Heizer and Treganza 1947:300-310

5. Spears 1892:77-78

6. Lantis $1963: 42,68$

7. Ainsworth 1965:20

Hussar $1977: \mathrm{E} 2$

Wilke and Lawton 1975:23

8. Bean and Mason 1962:36-37

Blake 1856:95-96, 435

9. Heizer and Treganza 1947:305-306 Bard 1973:35

10. Bard 1973:35

11. Federal Writers'

Project 1939a:637

12. Heizer and Treganza 1947

13. Davis $1974: 30$

14. Davis $1974: 29-30$

15. Ezel1 1968:28-34

16. Sample 1950

Schroeder 1952:40, 43
17. Davis 1974:45

18. Bard 1973:38

19. Laird 1976

20. Weide and Barker 1974

Figure 2

21. Davis 1974:20

Spier 1933:349

Gifford 1931:23, 25, 37-40

Drucker, 1941:172

22. Lucas 1976:personal communication

23. Davis $1974: 27,32,36$

24. Kroeber $1970: 788$

25. Kroeber $1970: 788$

26. Kroeber 1970:596

27. AAUW 1953:26

28. Kroeber 1970:711

29. Kroeber 1970:788

30. Kroeber $1970: 596$

31. Gudde 1949 
CHAPTER 2. THE 1540-1846 PERIOD: SPANISH AND AMERICAN EXPLORATION AND THE OPENING OF THE DESERT.

In mid-summer 1540 the Spanish explorer Hernando de Alcarón sailed up the Colorado River in small boats as part of a major overall expedition directed by Francisco Coronado. Although it is unclear exactly how far upstream Alcarón and his party travelled, it appears that he sailed at least to a point significantly above the Colorado-Gila confluence near the head of the Colorado River Delta. ${ }^{1}$ Alcarón encountered as many as ten native American groups during his travels. The names applied by Alcaron to the native groups are, in some cases, known to document the presence of ethnic groups that occupied the area in later, better-documented years. 2

A second Spanish intrusion was made in September 1540 when Melchior Día marched from Sonora toward the Colorado River in search of Alcarón. 3 Díaz failed to meet up with Alcarón, who had headed back to New Spain. Ironically, Alcarón was impaled on his own lance during a hunting mishap, and following a three-week bout with infection and fever, succumbed and was buried in the uncharted wilds. 4

More than six decades later, Juan de oñate marched downstream along the Colorado River entering its floodplain somewhere near Bil1 Williams Fork. On January 25, 1605, Oñate and his party, led by native guides, encountered the mouth of the Colorado River. Based on Oñate's description of the land and of several large native settlements (Oñate estimated as many as 5,000 inhabitants), 
the Spanish viceroy proposed that a presidio be established at the river mouth, but no action was ever taken to implement such a plan. 5

Over the next two hundred years Spanish missionaries, colonists and military focused their attention on the development of Spanish strongholds throughout present-day Sonora, Arizona and southern parts of Baja California. The Colorado River and the vast stretch of 1 and to the California coast went unexplored and unnoticed until impetus rose for future colonization and exploration.

Two short and seemingly unimportant (for the purposes of this study) overland treks were made to the Colorado River by a Jesuit priest, Father Eusebio Kino. ${ }^{6}$ Father Kino's visits in 1701 and 1702 were instrumental in advancing the idea that California was a land mass contiguous with the rest of New Spain and not an island as others had suggested. Acceptance of Kino's idea fostered hope of an overland route from Sonora to Baja California and the California Desert. Thus, although Kino probably did not cross the Colorado River and enter the CDCA, he may have laid the groundwork for events to come.

Mission San Diego de Alcala was founded in 1769 following an overland expedition from Loreto, Baja Calfornia, supplemented by supply ships from San Blas in Nayarit. The establishment of the mission and presidio at San Diego was the first link in the forging of the California mission chain. The hardships and ardors of supplying the burgeoning California missions further stimulated exploration and charting of the Yuha Basin/Imperial Valley region. 
In 1771 Father Francisco Garces led an expedition from Tucson to the general area of present-day Yuma. From Yuma Garcés went to the mouth of the Colorado River and travelled south into Baja California, staying north of the Cocopah Mountains. Somewhere near the Mount Signal/Calexico area, Garcés reversed himself and returned to Tucson. ${ }^{7}$ Garcés excitedly told Juan Bautista de Anza of his trek and insisted that a route through the mountains west of the Yuha Basin could be found and that a route to the California Coast was assured. ${ }^{8}$ Anza acted on Garcés' recommendation and secured permission from Spanish authorities to attempt an overland crossing from Tubac to Mission San Gabriel.

Ironically, the desertion of two soldiers from the Presidio de San Diego in 1772 prevented Anza from being the first European to traverse the seemingly formidable mountain barrier between the coast and the desert. Instead, it was Commandante Pedro Fages who, while in pursuit of a pair of deserters, breached the Cuyamaca Mountains, travelled down Oriflamme Canyon and entered the Yuha Basin. ${ }^{9}$ Fages and his men, however, left only scant documentation of their travels in the Yuha area.

Almost two years later Anza and Garcés left Tubac, led by a Christian native runaway (Sebastian Taraval), with the intent of opening a southern route from Arizona/Sonora to coastal California. When Anza and Garcés arrived at the Yuma settlements at the mouth of the Gila River, they were well-treated by friendly Yumas. From this point to approximately Calexico, the party followed the route traversed three years earlier by Garcés. This route kept the 
explorers south of the present-day International Border. Near Calexico the expedition entered California and continued in a general northwesterly direction. 10

The explorers passed Yuha Well, San Felipe and Carrizo Creeks, Borrego Springs, up Coyote Canyon to San Jacinto Valley and then across the broad plain to Mission San Gabriel. With his arrival at San Gabriel on March 22, 1775, Anza had established a 600-mile-long southern overland route to western California. ${ }^{11}$ The following year Anza made a similar trek across the desert, thus solidifying the feasibility of the route.

Between 1776 and 1781 the Anza/Sonora Route was the major transportation route between the California missions and the Arizona/Sonora region. Two outposts, as yet poorly documented, were founded near the Yuma settlements along the mouth of the Colorado River to ensure safe travel through the area. The La Purisma Concepción settlement was established in 1781 near the Gila River-Colorado River junction, apparently on the west bank of the Colorado. ${ }^{12}$ Farther south, a second outpost was begun at San Pedro y San Pablo de Bicuñer. ${ }^{13}$

Following a year of harrassment by Spanish settlers and severe depletion of native food stuffs by grazing cattle, Yuma warriors attacked both ill-equipped settlements on July 17, 1781. The churches and other structures were razed and the male occupants, including Garcés, were slain; females and children were taken captive. ${ }^{14}$ Although Pedro Fages and his men spent part of the next year travelling the Anza Trail and ransoming captives, ${ }^{15}$ the Yuma 
insurrection of 1781 effectively closed the Anza/Sonora Route to most travellers with the exception of occasional treks such as that of Jose Joaquin Arillaga in 1796. Arillaga traversed the western portion of the trail when he left northern Baja California and entered present-day San Diego County on his way to the Mission San Diego de Alcalá.

In 1829-1830 Antonio Armijo journeyed from New Mexico to California seeking a commercial trade route across the California Desert. Wary of Yuma attacks, Armijo entered the study area at a point north of Needles, thus avoiding Yuma settlements. Exactly where Armijo entered California is a hotly contested academic problem. Traditionally, his route, and thus the opening of the old Spanish Trail, has been ascribed (by LeRoy Hafen) to an entry point near Pahrump Valley, then on to Resting Spring, Salt Spring, Bitter Spring, and southwest to the Mojave River-Barstow area. ${ }^{16}$ From Barstow, Armijo followed the Mojave River to the base of the San Bernardino Mountains and then through the Cajon Pass into the flatlands east of San Gabriel.

More recent research by Dennis Casebier indicates that Armijo may have entered California south of the route generally accepted by historians. Originally, Casebier hypothesized that Armijo passed into California near the Mesquite Valley area on his way to Kingston Spring. ${ }^{17}$ However, following the research of Elizabeth Von Till Warren, Casebier and others now speculate that Armijo may have travelled through the Piute Valley and linked up with the ancient Mohave Trail. Based on current research, this more southerly 
route for Armijo and for what became known as the 01d Spanish Trail seems well-founded. 18

The route opened by Armijo became the major, although by no means sole, trade route between New Mexico and California. Woolen goods and other manufactures were transported along this route to California where they were traded for horses and mules, which were driven back to New Mexico. The Old Spanish Trail served not only as a busy commercial trade route between 1830 and 1848 , but it was also used by emigrants and, occasionally, by trappers. ${ }^{19}$ Horse thieves from New Mexico and Sonora made periodic raids on California communities and drove their spoils back to Sonora where there was a ready market for pack animals.

Two other alternative routes have been proposed for the old Spanish Trail and are relevant to this study. One route entered California north of Armijo's route between Death Valley and Shadow Mountain, crossed the Amargosa River, entered Greenwater Valley, skirted the Saddle Peak Hills and linked up with Armijo's route southeast of Saratoga Springs and north of Silurian Lake. Although this route was no doubt used during the 1830-1848 period, it was probably not as popular as the more southern route unless travellers came from the Salt Lake area. In later years this route became the Salt Lake-Los Angeles Wagon Road.

A third possible alternative for the old Spanish Trail entered California north of Mesquite Valley within Pahrump Valley, travelled west to Resting Springs at the southern end of Chicago Valley, and then dropped down to Salt Spring (later Mormon Diggings) 
where it joined with the more northerly route from Salt Lake. This route is the more traditional route ascribed to Armijo and thus, by implication, for the 01d Spanish Trail. This route was probably used by those persons seeking a more northern exit from California or by persons seeking to avoid contact with fellow travellers (such as horse thieves).

Further research will be required to determine the actual route of the 01d Spanish Trail and its correlation to Armijo's trail. It seems probable that over the years (circa 1830-1848) traders, emigrants, horse thieves, and adventurers could have used any, or all, of the suggested routes. Choice of a particular route would have been dependent upon the ever-changing availability of water and the point of origin, i.e. Salt Lake versus Las Vegas. The unpredictable attitudes of Mohave villagers toward non-Indian travellers in and around Piute Valley may have dictated against use of that entry point and forced a shift to the north. Later pioneer American travellers who entered California through the general area between Needles and Death Valley Junction noted that they had followed portions of, or the entire length of, the "Old Spanish Trail," perhaps indicating that over the years a general label or title came to encompass a variety of trails or routes. The first Americans came over the trail in $1841 .{ }^{20}$ With the outbreak of the Mexican-American War, traffic on the Old Spanish Trail slowed, became sporadic, and by 1848 ground to a halt. ${ }^{21}$

The effect of 01d Spanish Trail on historic land use in the CDCA was minimal because the trail served as a passage route 
between New Mexico and coastal California rather than as an artery to serve the desert regions. This major transportation route across the eastern California Desert instead had more effect on land use at both ends of the route, i.e. Los Angeles/San Gabriel and Tucson/Sonora, than it did across the hundreds of miles it traversed.

Existing springs or natural wells such as those at Salt Spring, Resting Spring, Bitter Spring and Piute Spring may have been expanded or altered somewhat, but the forces of nature and the impacts of later travellers have erased whatever scant marks would have been left on the land. Similarly, Spanish or Mexican temporary or overnight campsites near water or shelter are reflected more in historical documents than in physical manifestations. There is no record of the establishment of permanent outposts, forts or rest areas along the old Spanish Trail during this period.

The extensive Mohave Trail, forged and frequently used by Mohave traders and raiders between Piute Valley and the California coastal plain prior to Spanish contact, became a second major European trade route. In 1775-1776, Francisco Garcés and Juan Bautista de Anza began a second major expedition to central California. Anza entered California via the Anza-Sonora Route while Garcés continued up the Colorado River to the Mohave villages north of Needles. ${ }^{22}$ Although some historians have suggested that Garcés did not go beyond Needles but instead struck out westward toward the Piute Mountains, it seems more likely that he made it to the Mohave villages near present-day Fort Mojave. 
Garcés left the Mohave villages with native guides leading the way across the desert to the west. ${ }^{23}$ Although it is probable that the major Mohave Trail was located south of the Garcés route, the Mohave guides may have led Garcés along the more circuitous northern route because it afforded more water and pasturage than did the southern route. It is an interesting aspect of variable land use to realize that native American runners and travellers could and did make regular use of trails and routes that were impractical for European pack animals, wagons and mounted men.

Garcés apparently crossed Piute Wash near the site of Klinefelter Springs, travelled through Foshay Pass in the Providence Mountains, skirted the Kelso Dunes near present-day Flynn, to a point on the west shore of dry Soda Lake near Soda Springs. ${ }^{24}$ At Soda Springs, Garcés crossed what would later be the intersection of his more southerly, less travelled route and the northern route which would become the famous Mohave Trail/Mohave Road-Government Road route, as discussed later.

From Soda Springs Garcés pioneered (at least for Europeans) the Mohave Trail parallel to the Mojave River from the Cady Mountains southwest to the southern edge of the Calico Mountains. Near present-day Yermo, Garcés crossed a point that would become known as "Forks of the Road" because eastbound travellers could elect to branch off at this point and head northeast up the old Spanish Trail. 
Garcés left Forks of the Road, passed near what is now Barstow and generally followed the Mojave River drainage along its southern course to the foothills of the San Gabriel/San Bernardino Mountains and out of the CDCA. Garcés found, or more correctly was shown, a pass through the mountains and pushed on across the Cucamonga Plain to Mission San Gabriel. After a short rest and resupply period at San Gabriel, Garcés and his native guides reversed their travels. They left the Los Angeles Basin, proceeded through Cajon Pass, travelled across the western Mojave Desert to a point near Forks of the Road (Yermo) and then continued to retrace his route east to Soda Lake.

At Soda Lake Garcés veered off from his earlier route and traversed a more northern trail that led him along Indian Creek and Willow wash then to a spring that would be known later as Marl Spring. From this point Garcés meandered across the Kelso Wash, found a pass through the Mid Hills, and drove on through the wide Lanfair Valley to Piute Creek. At Piute Creek, Garcés headed south-southeast along the creek to Klinefelter Springs and joined with his original westward route. Garcés exited California and the CDCA north of Needles and returned to Tubac.

The contribution of Garcés and his trek was that he opened up a new Spanish route between Sonora and western California, thus proving that a more central route than the Anza-Sonora Route was a feasible means of supplying the California missions and settlements. The Garcés-Mohave Trail route took on particular significance with the closing of the Anza-Sonora Route as a result of the Yuma uprising in 1781 . 
If Casebier and Warren are correct in their assertion that the O1d Spanish Trail entered the CDCA near Piute Springs, then its linkup with the Garcés-Mohave Trail was almost immediate of that point and the Garcés-Mohave Trail constituted a major segment of the old Spanish Trail. If traditional historians are correct, the old Spanish Trail entered California considerably north of Piute Creek and did not intersect with the Garcés-Mohave Trail until Forks of the Road near present-day Barstow. The significance of this argument to the current study is one of academic preciseness rather than of historic land use. If the Garcés-Mohave Trail and the 0ld Spanish Trail are one major trail system, then that route received the bulk of activity between 1781 and 1848. However, if the more northern entry points for the old Spanish Trail are correct, then the Garcés-Mohave Trail from Forks of the Road east to Needles went virtually unused by Europeans until the American Conquest.

The unmarked and apparently unknown nature of the Mohave Trail is evident from the difficulty experienced by Gabriel Moraga in 1819. Moraga led an ill-fated military mission across the desert with the intent of raiding the Mohave villages as punishment for their recent attacks through southern California, including a major incident at Mission San Buenaventura. ${ }^{25}$ Although in pursuit of the fleeing Mohaves, Moraga was unable to chart a clear path across the formidable desert. Somewhere east of Devil's Playground near Kelso, Moraga and his fifty-man punitive party ran dangerously low on water and supplies. ${ }^{26}$ The squadron that had hoped to enter the 
Mohave homeland and punish the infidels instead found themselves returning to San Gabriel without finding the apparently elusive Mohave Trail, or the equally elusive Mohave. 27

The virtual abandonment of the Anza-Sonora Route between 1781 and 1848 , and the circuitous route afforded by the old Spanish Trail made the search for a shorter, more direct inland route to coastal California a high priority. Native American traders had probably used a direct route between their settlements near present-day Blythe and friendly villages in the Los Angeles Basin, as described earlier. ${ }^{28}$ When a Cocomaricopa (Maricopa) chief or leader arrived at Mission San Gabriel in 1821, he announced that he and his companions had covered the distance from the Colorado River in six days. ${ }^{29}$ Although this chief, José Cocomaricopa, had come to trade for Mexican wares, a year later he and other Cocomaricopa runners were carrying official documents between San Gabriel/Los Angeles and Sonora. 30

Spanish use of native American mail carriers was a common practice by 1822. 31 In 1692 Father Saeta of Tubutama, Sonora used a native messenger to deliver his dying words to Father Kino, who was stationed in Dolores. Subsequent use of native runners and messengers, in particular Halchidhomas and Cocomaricopas, was wellrecognized.

The so-called Cocomaricopa Trail, as described in the previous chapter, travelled from points east of Blythe westward along a route approximating present-day Highway 10 across Chuckwalla Valley, traversed the Mecca/Indio area through Coachella Valley and continued 
over San Gorgonio Pass to San Gabriel. ${ }^{32}$ The realization that native runners could make the eastward trek in six days, coupled with the fact that the route avoided the unpredictable and often dangerous Yumas in and around Yuma Crossing, tantalized the Mexican officials. The Governor of Sonora, Antonio Narbona, and other officials advocated exploration and use of the Cocomaricopa Trail as a major mail route. To that end, José Romero and José Maria Estudillo were sent to find the trail and report back to Mexican officials.

Romero and Estudillo left Mission San Gabriel in 1823, led by a Juaneño guide who had been to Tucson several years earlier and reputedly knew the Cocomaricopa Trail. Although the guide managed to steer the Mexican explorers through San Gorgonio Pass, down Coachella Valley and out into the Colorado Desert, he was unable to lead them beyond that point. Romero and his weary, parched party probably got as far as the Chuckwalla Valley/Palen Lake area before they aborted their mission and turned back. They were unaware that they were less than thirty-five miles from the Colorado River. 33

A second expedition by Romero in November 1824 was led by Cocomaricopa guides and proved successful. On the second trek the Romero party followed a more southern route upon leaving the Orocopia Mountains/Salt Creek area and in doing so stayed within range of water sources while travelling along a route well-known to their native guides. 34 Romero later reported that although the Cocomaricopa Trail was passable, it was inferior to the Anza- 
Sonora Route. However, it was used during the Mexican period for salt entradas to the Salton Sink. 35

The length of the Anza-Sonora Route was drastically diminished by the discovery of the San Felipe Valley corridor linking Carrizo Valley and San Jose Valley. This time-and-energy-saving route was discovered by Santiago Arguello while pursuing native horse thieves eastward from the Presidio de San Diego. Arguello's discovery of San Felipe Valley occurred between the two Romero treks and seriously diminished the significance of Mexican discovery of the Cocomaricopa Trail.

Mexican officials compared the Arguello-Fages-Anza Trail with the Cocomaricopa Trail and opted for the former. This trail was soon known simply as the Sonora Trail or Sonora Road and began to see some use by early 1826. Sporadic native attacks and intratribal warfare caused some disruption of travel and led to abandonment of an as yet poorly documented outpost of Laguna Chapala. The exact location of this small redoubt, which lasted less than a year before natives sacked it, is not known, although researchers from Imperial Valley College may be excavating its ruins at a point east of Westmorland. Because of native hostilities, real or rumored, and the fact that few persons outside of the Southwest knew of the Sonora Road, the more well-known, and by now wellestablished, 0ld Spanish Trail/Mohave Trail complex continued to serve as the major trail system into California in spite of its inconvenience. 
As the war between Mexico and the United States broke out, the Colorado Desert, the Mojave Desert and Yuha Desert still remained largely uncharted, untrammeled and ill-perceived. The old Spanish Trail served as an emigrant trail, a commercial road and a marauders' escape route. Pack trains, horse drives and trapping parties had passed across this route (or routes), but with little effect on the surrounding area. Natives still controlled the land, nature still prevailed, and permanent settlements or use of the land beyond the trails themselves were neither desired nor pursued.

The Cocomaricopa Trail was never a major Spanish-Mexican trail. It ceased to serve as a mail route via Cocomaricopa runners sometime between the great meteorite shower of 1833 and Halchidhoma migration to the Gila River in 1838. The Anza-Sonora Road was perhaps the most travelled road during this period, although comparisons with the old Spanish Trail are difficult to assess. One contemporary estimate notes that almost forty percent of the Spanish colonists traversed the Anza Trail before the Yuma uprising in 1781. However, again it should be noted that the trail, or trails, constituted the sole land use throughout the area. Construction of permanent wells, way stations, mining towns, and military installations was several years and another culture removed from the sunset of the Mexican period in 1846 . 
1. Federal Writers' Project 1939a:636

2. Aschmann n.d.:247-248

3. Steere 1952:27

4. Aschmann n.d.

5. Aschmann n.d.:246-247

6. Federal Writers' Project 1939a:636

Aschmann n.d.:247

7. Lindsay 1973:42 Pourade 1971:12-13 Bolton 1930:I:31-32

8. Bolt on 1930:I:209-219

9. Lindsay 1973:44

10. Lindsay 1973b:42 Bancroft 1885:II:43 Bolton 1930:i:65

11. Pourade 1960:157-158

12. Federal Writers' Project 1939a:636

13. Edwards $1969: 252$

14. Aschmann n.d.: 248

Bean and Mason 1962:3

15. Leadabrand 1969:119

16. Hafen and Hafen 1954

17. Casebier 1975:31-32

18. Warren and Roske 1978:1-20

19. Edwards 1969:149

Casebier 1975:31-32

20. Bard 1973:43
21. Casebier 1975:37

22. King and Casebier 1976:283-284

23. Bard 1973:38

24. Otis $1977: 113$

25. Turner $1974: 125-126$ Bancroft 1885:II:332-336

26. Bard 1973:40

27. Bancroft $1885:$ II:336

28. Bancroft 1885:II: 332

29. Turner 1974:125

30. Baxter 1968:40 Bancroft 1885:II:507-508

31. Oneal 1957:21 Ezell 1968

32. Turner $1974: 124$

33. Turner 1974:123-124 Bean and Mason 1962 Bancroft 1885:II:507

34. Lindsay 1973:54

35. Edwards 1969:100, 242 
CHAPTER 3. THE 1846-1868 PERIOD:

AMERICANS IN THE DESERT;

EXPLORATION, RAILROAD SURVEYS

AND MILITARY ACTIVITY.

Although several American trappers and adventurers are known to have passed through California in general, and desert areas specifically, during the Mexican period, their impact was probably negligible. Men such as Jedidiah Smith in 1826-27, James and Sylvester Pattie in 1826, David E. Jackson in 1831, Richard Campbell in 1827, and Thomas Coulter in 1832 used either the Sonora Road or the old Spanish Trail to enter or leave California. The fragmentary nature of their descriptions and their ephemeral effect on the land dictate that only a passing note be made of these men. Although the literature on the exploits and adventures of Smith, Pattie and Jackson is abundant, the significance to the current study is minimal.

The Mexican War brought several famous and significant exploration parties to California. In 1846 General Stephen M. Kearny (Kearney) and Kit Carson marched into the CDCA from Pima territory along the Gila River. Kearny and his Advance Guard of the West had gone into Baja California probably along the old Sonora Road out of Yuma. After skirting Alamo Mucho, the party travelled northwest and entered present-day California east of Signal Mountain.

From the Signal Mountain area, Kearny continued northwest but travelled farther north than the more western-trending route taken by Anza and other early emigrants. Near present-day El Centro, 
Kearny headed almost due west past the wells later known as Sackett's and into the well-travelled Carrizo Corridor. Kearny and his parched, weary men camped at Vallecito near a large Kumeyaay village, then marched on the abandoned village at San Felipe. After finally crossing the mountains, they marched out onto San Felipe Valley near Warner's Ranch. After insufficient rest and resupply, Kearny and his men continued their 1,500-mile odyssey, to meet their fate at the battles of San Pasqual and Mule Hill. Seven days after their weary arrival at Warner's, at least nineteen members of Kearny's army were dead. Kearny himself had received two severe punctures through the buttocks, the handiwork of Andreas Pico and his Californios.

A large party of more than 350 Mormons were less than two months behind Kearny and generally followed his route. However, their large wagons necessitated some route alterations, or in the case of Box Canyon, alterations in landform. In order to pass through the slender gorge at Box Canyon, the emigrants actually picked, quarried and smashed a corridor just wide enough for their wagons. The successful passage of the Mormons, coupled with Kearny's march, opened up the Emigrant Trail or Gila Trail into southern California.

Although this route from Yuma west followed the Sonora Road for the most part, its first extensive use was marked by pack train and wagon alike. The traffic which plied the Emigrant Trail included military units, Sonorans bound for the gold fields up north, American emigrants, commercial traders and occasional natives. The trail 
was not without its hardships. Yumas still made sporadic raids on ill-defended wagon trains, lack of water felled even the hardiest livestock, and broken wagons were abandoned for want of spare parts and spare teams. Cherished articles, extra food and other "surplus" items were cached or outright discarded to lessen the load or to make room for less fortunate travellers. Yet, the march west continued. In 1849 one authority noted that as many as 12,000 emigrants had travelled the trail since $1846 .^{1}$

The southern portion of the CDCA and the general area traversed by the Emigrant Trail had become generally well-known to experienced travellers, military men and wagon masters by 18481849. Boundary surveys by Amiel Whipple, Cave Couts Jr. and William Emory provided government officials with a better knowledge of the area and have left researchers with a wealth of ethnohistoric and anthropological data.

Increased and steady traffic, combined with the need for military protection from natives and white vagabonds, led to the establishment of several early way stations along the Emigrant Trail. At Vallecitos, a small number of soldiers, horses and supplies were kept as early as $1850 .^{2}$ Apparently, the depot was adjacent to the then still-inhabited Kumeyaay village at the same location. Similarly, the much larger camp at Fort Yuma was also founded among native villages, in part as a control mechanism and in part because the site was at a major intersection of trails. The first occupation of Fort Yuma proved to be short-lived. In early summer of 1851, the majority of the troops and equipment at 
Fort Yuma were transferred to Santa Ysabel, and the small squad left at the fort departed in late summer of that year. In later years Fort Yuma was re-garrisoned and was a significant factor in pacification of the Yumas and in asserting military might in California.

Thousands of emigrants poured into California from the south, and an impressive number of gold seekers and settlers traversed the Old Spanish Trail near Death Valley. Perhaps the best-known of these were the so-called $49 \mathrm{ers}$, who entered California well above the old Spanish Trail and stumbled into Death Valley in their haste to make a shortcut to reach western California. Their numbers were few; consequently, they had little effect on the land. Leaving the valley, they split into several groups. The Manly Party left Death Valley along the Amargosa River, went across the Panamint Range towards Searles Lake and into Indian Wells Valley; they left more descriptions of their plight than impacts upon the land, beyond initiating the use of Death Valley as a traffic corridor. ${ }^{3}$ The Jayhawkers and other parties, who stayed west of the Amargosa River and travelled over Emigrant Pass to Panamint Valley and then across Searles Lake, initiated a route that was important during the later mining periods.

South and east of Death Valley, the Mohave Trail once again came into use and soon became a major traffic corridor. Portions of the Mohave Trail from Cajon Pass to a point east of Forks of the Road were traversed by John Charles Fremont during his 18431844 trek from Tehachapi Pass to the Colorado River. Fremont, and 
other trapper-explorers who followed a similar route, made it clear that the Mohave Trail-old Spanish Road was a feasible route across the Mohave Desert. It has been speculated that American travellers apparently thought that they could tame the insolent natives, forge shorter and better routes to the south, and generally succeed where the Spaniards and Mexicans had failed.

During this time - about 1851-1852 - the Federal Government sent Indian Commissioners to assess the location, numbers and needs of thousands of native Americans throughout California. The over-zealous commissioners formulated treaties that they were not authorized to establish and made promises of land grants which the government had not authorized. 4

It is difficult to assess the role, if any, played by natives within the CDCA in the treaty negotiations. Several villages in or near the study area were officially represented during the illegitimate treaty negotiations; among them were Vallecitos, San Felipe, Tecate, and Santa Ysabe 1.5

Apparently, large blocks of land were unofficially set aside as reservations or tracts for the exclusive use of native Americans. One large tract was within the southern portion of the CDCA (Figure 2) and two other tracts were situated along the westcentral boundaries. The entire package of 18 treaties was not accepted by the Federal legislature and the unauthorized treaties went unratified. Because they were never established nor settled, the unratified reservations in and around the CDCA had no effect on 1 and use. 


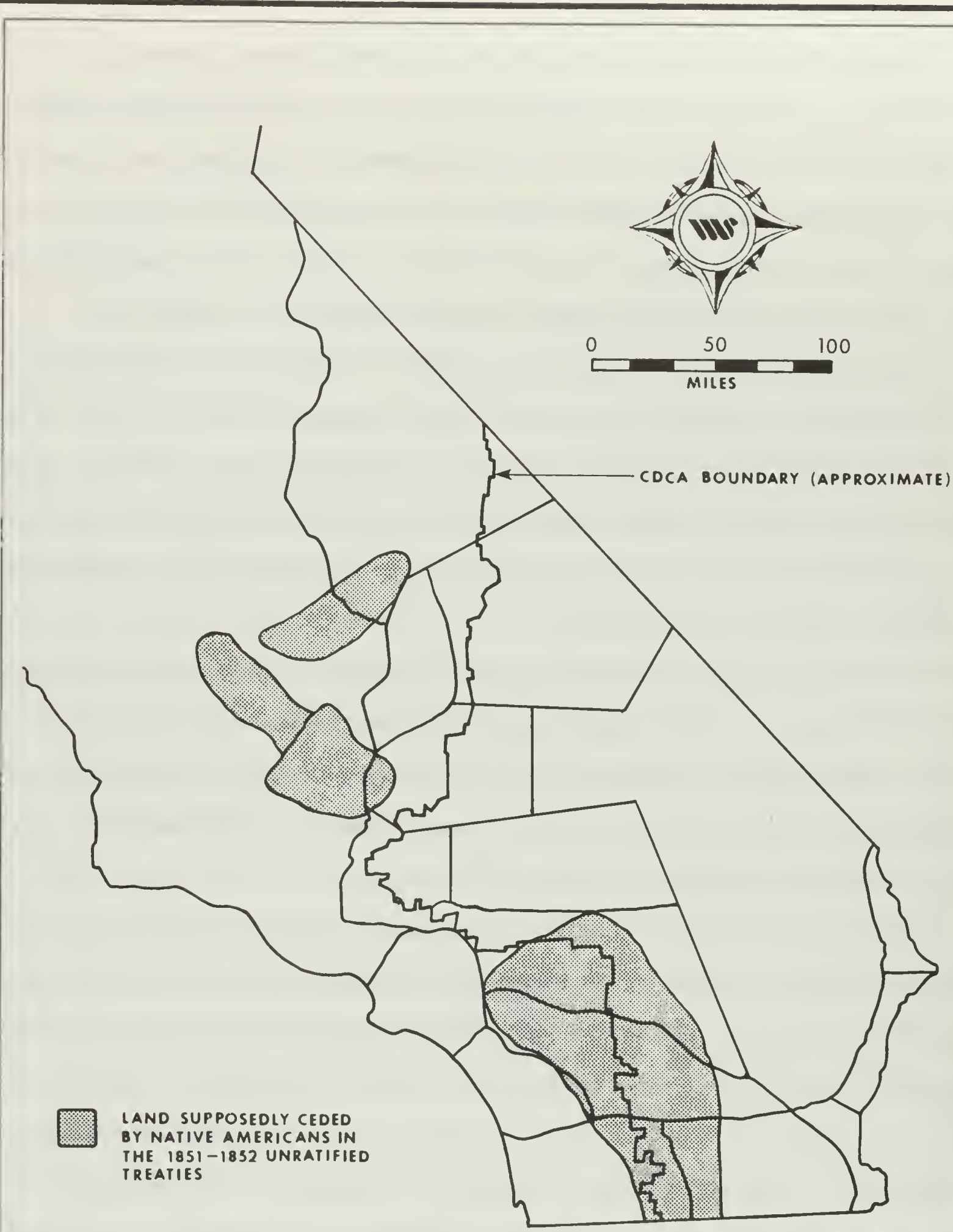

Source: Heizer, 1972

Approximate Locations of Unratified Treaty Land (18511852) In and Around the Study Area.

FIGURE 
Between 1853 and 1860 a series of railroad surveys were conducted in various areas, one of which centered around the Mohave Trail. Well-known surveyors such as Amiel Whipple, as well as then unknowns such as Francis X. Aubrey, Edward F. Beale and R.S. Williamsen, spent several months surveying and evaluating possible routes for permanent wagon roads and potential railroad beds. 6 Aubrey travelled with an entourage of well-armed men and went unmolested by natives or white marauders. Whipple also had a minimum of troubles with natives, although Beale and others were harrassed.

One of Beale's tasks was to determine the feasibility of opening a wagon road across the desert following the Mohave Trail or 35 th parallel route. Feasibility was dependent upon availability of water and grass, ease of travel, and safety. Beale regarded this route as able to fulfill all of these criteria and suggested that camels be used as pack animals to augment the wagon trains. ${ }^{7}$

Beale's optimism for the Mohave Road failed to take into account the warlike Mohave villages near Needles. The increase in emigrant activity and traffic across the Mohave Road provided an opportunity for the Mohave to exploit the American travellers as they had the Spaniards and Mexicans. Small bands of raiders made sporadic raids on wagon trains without fear of serious reprisal and effectively closed down the road itself and emigrant activity across the river. 
Mohave control of emigrant traffic was short-lived. The establishment of Fort Mojave, coupled with increased military activity under Captain Winfield Scott Howard and a series of native battles that proved unsuccessful for the Mohaves, broke their stranglehold on the Mohave Road by late 1859. To further protect the route, outposts were founded at Camp Sugar Loaf (near Barstow) in 1858; Fort Piute or Fort Beale in 1859-60; Camp Cady in 1860; Camp Mar1 in 1865; Camp Rock Springs in 1865-66; and Fort Soda in 1865-66. Farther north, a redoubt at Resting Spring was established in the early 1860 s along the 01d Spanish route. ${ }^{9}$ None of the forts were occupied past 1870 , but by that time they had become unnecessary.

With protection of the route assured, the way was opened to civilian growth. Among the first to populate the route were suppliers; in this fashion, Lane's (Oro Grande), Grapevine (near present-day Barstow), Fish Pond (later Nebo), and Hawley's (near Yermo) were established to serve the needs of travellers. And to an increasing degree, miners began to filter out into heretofore undiscovered areas. Some mining activity had begun earlier; for example, gold had been intermittently extracted from the Salt Spring "Mormon Diggings" area as early as the $1830 \mathrm{~s}$ and again about 1850. 10 The Potholes area near Laguna Dam saw the state's first mining boom back in 1781. 11 However, the growth of mining towns and mining activity did not begin in earnest until after subjugation of the Mohave about 1859. Discovery sites, largely prompted by a search for the Lost Breyfogle Mine from the Death 
Valley 49ers' trek, centered in the northern deserts; mines in the 1860 s were often worked by Mexicans, as the El Paso, Picacho and Cerro Gordo areas suggest. ${ }^{12}$ Other discoveries before 1868 occurred at Vontrigger, the Slate Range, the Coso District, the Wildrose area, and near Camp Rock Springs. ${ }^{13}$ The latter camp brought about the desert's first post office, but none of these areas were significant nor long-lasting. As well, many miners going to La Paz, Arizona (near Blythe) traversed the Bradshaw Trail after it opened in 1862; however, no significant mines and only a few way stations resulted from the traffic. ${ }^{14}$

In summary, the American influence on the desert, particularly from 1846 to 1868 (and beyond, as discussed in subsequent chapters) was profoundly different from that of the Hispanic period. Whereas the Spanish and Mexican periods were typified by movement across or through the study area (as a result of exploration or military action), American efforts became focused on extracting and exploiting the resources within the study area itself.

The Spanish and Mexican influence consisted of thin strands of trails that linked together settlements on either side of the desert. The early American period witnessed the improvement of these still primitive trails and some effort to transform them into maintained roads with way stations, outposts and supplies; also, ranching was begun in the western Antelope Valley. ${ }^{15}$ The native groups that had virtually controlled the desert between coastal California and Sonora during the Hispanic period were 
subdued by Americans, conquered by the Mohave, or migrated beyond the study area into Arizona, Baja California and Sonora.

Human impacts or marks on the land were increased from temporary camps and sparsely travelled trails during the earlier periods to relatively substantial (albeit sometimes ephemeral) towns. The beginnings of large-scale mining to include stamp mills, tailings and water diversion took place during the 18461868 period. Permanent forts were constructed, thus laying the foundation for larger settlements and providing security that would be a growth inducement.

By 1868 , those impacts or activities that would seriously alter the face of the landscape or have a direct effect on the land had begun in the form of livestock grazing, military bases, major transportation arteries, large scale mining, and the growth of permanent settlements. The remaining chapters detail the ultimate effects and history of these land uses and several others not yet present in 1868, including farming and recreational activity. 


\section{CHAPTER 3 FOOTNOTES}

1. Bard 1973:45

Hayes 1929:46

2. Edwards 1969:263

3. Miller 1976:11

4. Kelsey 1973:229-230

Heizer 1972

5. Heizer $1972: 60-65$

6. King and Casebier 1976:280

7. King and Casebier 1976:280, 291-292

8. Bard 1973:47

9. Belden 1964

10. Miller $1976: 47-49$

11. Edwards 1969:249

12. Leadabrand 1969:51

13. Strong 1975b: 9

King and Casebier 1976:311

Federal Writers' Project 1939b:19, 69

14. Edwards 1969:167-168

15. Settle 1963:61 
CHAPTER 4. THE 1868-1885 PERIOD: INITIAL MINING AND RAILROAD IMPACTS OCCUR.

Though Americans had assumed jurisdiction over the California desert for almost two decades by the late 1860's, their impacts upon the desert had been minimal; away from the principal wagon roads and scattered mining areas, land-use changes were almost non-existent. However, the desert came to be nominally (if thin1y) populated during the ensuing two decades, and a framework of settlements lasting to the present day began to be established.

During this period, mining became the dominant economy in the desert, particularly in the years before the arrival of the railroad. Major discoveries were made in many areas, particularly in the northern deserts. The first major strike occurred at Cerro Gordo; silver and lead were discovered in 1865 by a group of Mexican miners, though a major camp did not appear until about 1868..$^{1}$ Cerro Gordo was truly a giant among camps; its importance helped focus early interest into that area, and helped spawn subsidiary growth in Owens Valley for supplies. ${ }^{2}$ Los Angeles benefited as a freighting terminus, and a short-lived but active steamship line was created on Owens Lake to transship ores. ${ }^{3}$ Freighting stations such as Little Lake, Gyote Holes and Willow Springs also came into existence at this time. ${ }^{4}$ The wealth at Cerro Gordo proved almost limitless; it remained a major producing area until the early years of the twentieth century and provided an intermittent source of wealth for decades afterward through the 
discovery of new veins and reworking of tailings dumps. Lesssuccessful adjacent camps, also located high in the Inyo Mountains, were established in the $1870 \mathrm{~s}$ at Belmont and Beveridge. 5 Other major camps appeared shortly afterwards, still principally in the northern desert. Ivanpah, a gold camp on the east slope of Clark Mountain, came into its own about $1870 ;^{6}$ reaching a peak in the late $1870 \mathrm{~s}$, production continued up to about $1900 .^{7}$ Activity also occurred about this time in Wyman Canyon in the extreme northern desert; the site supported a minor town called White Mountain City, of which little is known and even less can be deduced from present remains. ${ }^{8}$ Less major strikes in the 1865-75 period took place near Stoddard Wells (east of present-day Helendale), the Picacho and Oro Grande areas, and in the Twentynine Palms area. ${ }^{9}$

Perhaps the wildest desert camp ever appeared at Panamint, on a high ridge opposite Death Valley. Ore was discovered there early in 1873.10 Its site was in one of the most remote and inaccessible parts of the desert, however; thus news about the camp spread slowly. Panamint's peak years occurred in 1874 and 1875. During this period, it attracted many whose past was somewhat less than reputable; accordingly, the tortuous trip up the canyon into the camp was under constant threat of holdup. So dangerous was the trip that the Wells Fargo Company, the major bullion carriers of the time, refused to even serve the camp; the only way that the ore could be taken safely away from the camp was to cast the silver into 500-pound balls, and haul it by wagon 
across the desert to Los Angeles. Though the camp was already failing by 1876 , a July cloudburst washed almost the entire remains down Surprise Canyon. ${ }^{11}$ Small revivals occurred in later years.

Another major camp appeared at Darwin, where a silver-lead strike occurred in 1874. Originally situated downslope from its present site, the town immediately boomed, and soon had a population of 1,$500 ;^{12}$ an enterprising Japanese took advantage of the year-round flow at nearby Darwin Falls to set up small vegetable gardens in the narrow floodplain below. ${ }^{13}$ The town, after moving a short distance, experienced several booms after the $1870 \mathrm{~s}$; however, they never regained the activity of its initial boom. 14 Eventually becoming a corporate-dominated town, Darwin has never entirely ghosted, though mining activity in recent years has been small and intermittent.

To the east of Darwin, silver was discovered at about the same time on the east side of the Argus Range. The Modoc, Minnietta and Defense Mines were the major area producers, and the Lookout townsite was established as a supply center. ${ }^{15}$ A local smelter was needed for the ore, but with no local wood available, the adjacent Panamint Range was harvested instead. Charcoal kilns were built there, and the end product was transferred back to the Lookout smelter. ${ }^{16}$ production of the mines continued into the late $1870 \mathrm{~s} ;$ grain to supply the various freighting teams to this and other camps came from Furnace Creek ranch, which had been established in 1870.17 
Each of the above towns and camps were true frontier outposts, existing largely on their own and often connected to the outside world only by occasional freighting and staging routes. By the mid-1870s, however, this pattern became modified somewhat as the railroad made sites somewhat more accessible. ${ }^{18}$ As explained in the following paragraphs, railroad accessibility did help the general mining economy of the desert -- in fact railroad companies, sensing the advantages of mining discoveries along their service routes, actively promoted new sites -- but precious metal production received relatively few benefits from railroad accessibility.

The first railroad came into the area in early 1876, from Tehachapi down to Mojave, then to Los Angeles via the Antelope Valley and Soledad Canyon. ${ }^{19}$ Los Angeles became accessible by rail late in 1876; that same year, construction began to the east. Extending through San Gorgonio Pass, construction was completed to Indian Wells (now Indio) by the end of 1876,20 and the railroad reached Yuma by September, 1877. ${ }^{21}$ Later, the Atlantic and Pacific (now the Atchison, Topeka and Santa Fe) Railroad built eastward from Mojave to The Needles (now Needles) in 1882-1883.22 Both railroads were eventually linked up with eastern counterparts, but not until 1883 and 1884 , respectively. 23

Symbolically important as its presence was, the railroad had little immediate effect on land use, with the exception of the various section camps and station-houses constructed along the route itself. There was some alteration of trade routes, however, 
and most trailside way stations were forced to close. ${ }^{24}$ Areas away from the tracks were not settled because the advantages of southern California had not yet been made known to much of the rest of the United States. The deserts of California were even less known, and thus generally feared. ${ }^{25}$ (The names given to the early Santa Fe stations reflect this unfamiliarity. Stations in mid-desert, for instance, were given sarcastic names, such as Klondike, Nome and Siberia; and lacking other inspiration, stations east of Bagdad were alphabetically arranged: Amboy, Bengal, Cadiz, and so on.)

Land use impacts after the coming of the railroad continued to be almost solely related to the mining of precious metals, chiefly gold and silver. In Inyo County, the best-producing area of the time, the mines at Cerro Gordo, Panamint and Darwin continued their large outputs, while major new activity occurred at the Gunsight and Noonday Mines, creating old Tecopa (eight miles east of the present town). 26

In other areas, chiefly San Bernardino County, other discoveries were being made. In the late $1870 \mathrm{~s}$, a large silver deposit was uncovered in the Providence Mountains; the resulting Bonanza King Mine soon created Providence, a company town a mile north of the mine site. ${ }^{27}$ The productive Waterman Mine was discovered in 1880 , and Calico came into prominence north of present-day Daggett. 28 Calico was typical of many of the larger camps; discovered in 1880 , it boasted a population of 2,500 by 1885 and even spawned its own residential area, Goblerville. ${ }^{29}$ Calico also 
occupied a large area of its own, spanning the entire area between Wall Street and Odessa Canyons. 30 Along with most mining camps before the turn of the century, it had its own Chinatown, a school, a plethora of saloons, red-light spots and the usual assortment of drifters, rowdies and tinhorns. 31 Like many other mining communities, it burned during its heydey, with the water required to douse the flames being worth more than the structures themselves. 32

The most celebrated activity during the period, though hardly dominant in the economics of the desert as a whole, was the borax trade. 33 First operated from various spots in Death Valley, the trade later became famous for its twenty-mule teams (actually eighteen mules and two lead horses) when a manufacturing operation adopted them for its symbol. Operations began in 1882 from the Harmony and the short-lived Eagle Borax Works, the former acquired by Francis C. "Borax" Smith. The Harmony operation was augmented the following year when the Amargosa Borax works began production; summer temperatures there, at a "cool" 110-degree maximum, allowed operations that were impossible on the floor of Death Valley. 34 The one was carried to the railroad at Mojave via a series of watering tanks. 35

Compared to mining and the railroads, grazing and other activities were less economically significant, if more expansive. Ranchers occupied the entire western portion of the desert area and roamed along the mountain margins as far south as the AnzaBorrego area; ${ }^{36}$ extensive ranches also existed in the Chemehuevi 
Valley, north and west of present-day Cima, and in the high country in and around Lanfair Valley. ${ }^{37}$ Trail drives were another occasional feature of the economy; the old Government Road, the newer (Bradshaw) road, the Weaver Trail through the Twenty-nine Palms oasis and the Southern (Butterfield) Route were used for this purpose. 38

Anglo agriculture also began at this time, though it was a very small undertaking at first. The General Land office, caretaker of Federal lands, began its long history of agricultural grants with a small tract of land in the southern Antelope Valley. Settled in 1880 , the small colony there was soon followed by others later in the decade. 39

It is interesting to note that the Antelope Valley even sported a lumbering episode during this period. Probably the only example of commercial lumbering in the California desert, it occurred in 1884 and 1885. An English corporation, called the Atlantic and Pacific Fibre Company, was formed to harvest the "yucca palms" (Joshua trees) in the southeastern Antelope Valley for paper making operations. A pulp mill was set up at Ravenna, west of Acton, and several shipments were processed and sent to England. Operations ceased, however, when the first large shipment spoiled in transit. Though non-productive after 1885 , the company continued to own land in the area as late as $1915 .{ }^{40}$ 
1. Turner 1964

2. Murbarger $1964: 9,10$

3. Nadeau 1964

4. Edwards 1964

Farnsworth 1965:1

5. Murbarger 1964:15

6. Miller $1976: 61-62$

7. Bard 1973:50

8. Leadabrand $1972: 83-88$

9. Myrick 1975:437

Miller 1976:37-39

Miller 1968:9

10. Paher $1973: 42$

11. Paher 1973:42

12. Miller 1976:29

13. Federal Writers' Project 1939b:59

14. AAUW 1953:15

15. Murbarger 1964

16. Neal 1975:14

17. Paher 1973:7

18. Nadeau 1964

19. Settle 1963:27

20. Baxter 1968:41
21. Myrick 1962

22. Cook 1967c:22

23. Mojave River Valley Museum Association 1977

24. Bard 1973:58

25. Hanson $1896: 34$

26. Strong 1975:21

27. Bard 1973:72

28. Edwards $1969: 247$

29. Myrick 1962:816

30. Miller 1976:35

31. Otis $1977: 122$

32. Parker 1973:43

33. Federal Writers' Project 1939b:22

34. Paher 1973:18

35. Beck and Haase 1974:92 Federal Writers' Project 1939b:73

36. Ernst 1977

37. Bard 1973:51

38. Edwards 1969 Cook 1969d: 28

Bell 1932

39. Settle 1963:28

40. Settle 1963:29 
CHAPTER 5. THE 1885-1895 PERIOD: MINING PRODUCTION CONTINUES WHILE HOMESTEADING DEVELOPS,

PARTICULARLY IN THE ANTELOPE VALLEY.

In the late $1880^{\prime} \mathrm{s}$ and early $1890^{\prime} \mathrm{s}$, a number of basic changes occurred in the California desert. From a previous emphasis on railroads and mining, dry-farming agriculture and other attractions came into prominence, and previously-important mining towns began to give way to other mining areas. Railroads reached into some of these new areas, and transcontinental train travel dramatically increased.

Though the Atlantic and Pacific (Santa Fe) Railroad had completed its route from Mojave to Needles back in 188.3 , it did not receive a great deal of use until 1885 , when construction was completed between Waterman Junction (later Barstow) and Los Angeles through Cajon Pass. ${ }^{1}$ A major rate war ensued with the Southern Pacific soon afterwards, which reduced fares from Missouri Valley points to Los Angeles from $\$ 125.00$ down to $\$ 50.00$ and less for a short time. As a result thousands of visitors and emigrants entered southern California through the desert, touching off a major real estate boom from 1886-1888. At the time, however, the desert was thought by most as a less-than-desirable spot; it was a grim, lifeless place, to be avoided at all costs. ${ }^{2}$ Even so, portions of the Los Angeles area boom were felt in the desert. Several agricultural communities began in the southern Antelope Valley as a result; Neenach, Fairmont, Manzana, Del Sur and Almondale were several of the more successful towns, while the 
Chicago, Kingsbury, John Brown and Wicks colonies proved more ephemeral examples. ${ }^{3}$ Most of these colonies were founded by farmers with no real grasp of desert farming; as stated by Glen Settle, Antelope Valley historian:

The poverty of most of the settlers was one of the great factors, as well as their inexperience and general ignorance. Men were seen plowing only an inch deep and expecting the grain to take root and develop. 4

Compounding the problems were rabbit invasions, poor crop selection, and ignorance of deep-pumping or summer-fallowing techniques; as a result, several of these colonies barely began before they succumbed, even though these years were average or above-average in rainfall. Other homesteading attempts took place along the lower Mojave River, around Hesperia, in the Anza-Borrego area and in the Indian Wells Valley, generally with even less successful results. 5

Though small-lot subdivision activity from the boom of 1886-88 generally stayed in the Los Angeles basin and away from the desert, the later months of the boom brought some of the more flagrant, even fantastic examples of boom towns to the desert's margins. There were four prime examples of these subdividers' handiwork. Widneyville-by-the-Desert, a widely-advertised area near Hesperia, sponsored several train trips to the property as part of its sales campaign, and featured a grove of orange-laden Joshua trees as the focal point of the salesman's harangue. Lot sales were brisk, but no homes were built. ${ }^{6}$ Border City, near present-day Piñon Hills, was totally devoid of amenities "save 
that of a view," according to one report; and Manchester, near Border City, had many of the same attributes. ${ }^{7}$ The cynical claimed it was "accessible only by balloon," but since it was sold exclusively to persons outside the region, the four thousand lots, purchased by the developer at $2 \$$ each, were all sold at prices ranging up to $\$ 300$ per $10 .^{8}$ Palm Dale, today absorbed within Palm Springs' Smoke Tree Ranch, was slightly more legitimate, and even boasted its own rail spur; but like the others, it lasted only a short while. ${ }^{9}$ Palm Springs itself had its first boom during the late $1880 \mathrm{~s}$, but the failure of its irrigation system from Whitewater Creek delayed its development for several decades. 10

Due to the increased traffic and necessary facilities on the route, the railroads played a more important role in the desert. Barstow, with an 1890 population of 90 , had not attained any central function on the line yet; however Needles, with 285 people, had become the second largest town in the desert next to Lancaster. ${ }^{11}$ Mojave, with 231 residents, was next in rank, and most of the thirty or more stations in the desert had a small crew for maintenance-of-way and telegraph purposes. 12

Mining, particularly of gold and silver, continued to be dominant. Cerro Gordo, Panamint and Darwin, the various borax works and other Inyo County camps all decreased in importance; ${ }^{13}$ mines in San Bernardino and Kern Counties, however, were discovered and expanded. In the Clark Mountain area, Mescal, Nantan and Ivanpah were each active, while to the south, the Vanderbilt gold 
mine was enjoying its most successful period. ${ }^{14}$ The Nevada Southern (later the California Eastern) Railroad was constructed from Blake (later Goffs) to Manvel in 1893, providing access to that area. 15

Western San Bernardino County enjoyed continued mining activity. Operations were concentrated in the Oro Grande and Calico areas, though Copper City, the Dale District and other, less significant locations were also mined. The Oro Grande district, active since pre-railroad days, was the scene of a highly successful marble mine in 1886, as well as two silver mines 10cated in 1890.16 Calico, which had become a corporate operation in the mid-1880s, remained successful until the early 1890s, and after 1888 operated a spur line from its Silver King Mine to a mill located near Daggett. In 1892, however, the first of a series of silver price drops occurred, first diminishing and later eliminating the town's importance. ${ }^{17}$ Nearby, however, borate was being developed at Bismarck, and as borax operations phased out in Death Valley and adjacent valleys, they began to grow at this more accessible location. 18

Perhaps the most isolated of the mining camps were the gold mines at Dale, which had begun in the early $1870 \mathrm{~s}$ and were to last, more or less continuously, up to World War I. ${ }^{19}$ Dale was actually a series of three camps; the Virginia Dale camp was the site of the second Dale townsite, which lasted from the mid-1880s to around the turn of the century. ${ }^{20}$ The peak of activity in the area appeared in the early $1890 \mathrm{~s}$, with mines and prospects scattered over a wide area. 21 
The Kern County desert was the scene of extensive mining activity, principally in the early 1890s. Though Mexican miners had uncovered gold deposits in the E1 Paso Mountains as early as the 1860s, renewed placer discoveries in Goler Gulch in 1893 began a stampede of miners to that area. ${ }^{22}$ Red Rock Canyon, Last Chance Canyon, Summit Dry Diggings, and Tropico Hill (near Rosamond) were sites of ephemeral activity; ${ }^{23}$ most of these were past their peak when the Yellow Aster lode was uncovered on the opposite side of the valley. Discovered in April 1895, it soon spawned Rand Camp, the predecessor of present-day Randsburg. 24

Finally, mining activity took place in the southeast corner of the state in the Cargo Muchacho and Picacho Peak areas. Primarily Mexican miners worked the Picacho diggings, which were connected to the outside world by steamboats docking at the Picacho townsite. 25 In the Cargo Muchacho Mountains, gold was discovered by a Swedish trackwalker who had strayed off course; within months, the mining camp population at the Hedges townsite numbered over $3,000.26$ 
1. Dumke 1944

2. Edwards 1969

3. Settle 1963:30-36

4. Settle 1963:37-38

5. Bard 1973:74 Otis $1977: 130$

Lind say $1973 \mathrm{~b}: 75$ AAUW 1953:29

6. Bell 1930:270

7. Dumke 1944:188

8. Guinn 1890:18

9. James 1911:291

10. Otis $1977: 80$

11. Rand McNally and Co. 1897

12. Krutschnitt 1978 Bard 1973:68

13. Miller $1976: 18$

14. Bard 1973:71-73

15. Myrick 1962:843
16. Federal Writers' Project 1939a:613

Miller 1976:37

17. Paher 1973:43

18. Federal Writers' Project 1939a:605

19. O'Neal 1957:50

20. Miller 1968

21. Leadabrand 1966:159-165

22. Starry 1973

23. Federal Writers'

Project 1939a:521

24. Miller 1976:19

25. Myrick 1975:440

26. Federal Writers'

Project 1939a:638 
CHAPTER 6. THE 1895-1907 PERIOD: AGRICULTURE

BOOMS IN THE CALIFORNIA DESERT;

MINING DISCOVERIES SPREAD TO NEW

AREAS AS NEW RAILROADS MAKE ORE

SITES ACCESSIBLE.

In this, by far the most active period up to this date, several major events dramatically changed the appearance of the California desert. Most of these events occurred in the later part of this time period; by the time the Panic of 1907 loomed, to again alter the face of the land, the area was the scene of rapid change and the evolution of a wholly different landscape.

In terms of the desert's future importance, the creation, then loss of a canal between the Colorado River and the Imperial Valley probably rate as the most important series of events in the entire history of the California desert. For over fifty years, irrigation of the Valley had been the dream of Dr. Oliver P. Wozencraft; while the idea was generally regarded as impracticable and otherwise foolish, he tirelessly fought for funding that would bring about the construction of a canal. 1 Creation of the project, however, was to wait for the combined efforts of engineers Charles Rockwood and George Chaffey; construction finally began late in 1900, and the canal was finished in May of the following year. 2

The successful completion of the canal brought an immediate blossoming to the seemingly sterile desert soil. 3 Imperial, the first town in the valley, became a boom town virtually overnight, 4 and by 1904 Silsbee, Calexico, Heber (Bradtmore), Holtville 
(Eastside), and Brawley (Braly) had also become established communities. ${ }^{5}$ By the same year, the major Valley towns had been linked to the main line at Imperial Junction. ${ }^{6}$ El Centro was founded in the following year.

Then came the flood. Due to faulty and ill-timed repair work at the headgate of the dam near Yuma, the Colorado River overflowed its west banks in May of 1905 and streamed instead across Mexico and into the Imperial Valley. After the flood stage had passed, the river was restored to its former channel. Within months, however, the river again went on a rampage, this time flooding 488 square miles of farmland, ${ }^{7}$ and was not re-aligned back into its former channel until a combined effort from the railroad, farmers, and even President Roosevelt had been made. 8 Finally closed in February of 1907 , the canal left a dramatic imprint on the Valley: the town of Silsbee had been entirely washed away; many acres of farmland had been rendered unmanageable; and the once-level Alamo and New Rivers were left in 50-foot deep trenches. ${ }^{9}$ The Southern Pacific Railroad's right-of-way, an early victim of inundation, had to be moved five times. ${ }^{10}$ But the flood did not permanently impair most areas of the Valley, and indeed, the depressed river levels later proved beneficial in washing away the salt buildup from the Valley soils. 11

As much of a boon as this period proved to San Diego County's desert, the agricultural situation was much the opposite in Los Angeles County and other areas. Antelope Valley's agriculture up to that time was almost solely dependent upon rainfall for its 
water needs; consequently, when a succession of drought years occurred between 1895 and 1906, the region almost collapsed. Marginal farmland became totally unworkable; the most favorable farmland became, at best, operable with minimal crop yields. Lancaster became a ghost of its bustling former self, and several other farm communities came perilously close to extinction. ${ }^{12}$

In other areas, agriculture showed some modest growth. The Lower Colorado River Valley near Yuma began to be settled by nonNative farmers, though development proceeded slowly, ${ }^{13}$ and the Palo Verde Valley likewise began to show real signs of development. ${ }^{14}$ In the Coachella Valley, the discovery and proliferation of artesian wells allowed agriculture to expand substantially; ${ }^{15}$ dry-farming areas were homesteaded around Newberry, the Cronise Valley, around Superior Dry Lake, Apple Valley, and various parts of the present-day Anza-Borrego area. ${ }^{16}$

Spurred on by past discoveries and easier accessibility, miners fanned out into many previously unknown areas and found riches in other areas thought to be thoroughly prospected. As a result, highly successful mining ventures -- still chiefly gold and silver - - were widely established through the desert regions, creating several new short-line railroads. More minor strikes were found in almost all the desert ranges; some of these, manipulated by skilled financial entrepreneurs, became the region's best-known towns. Oil drilling also began during this period in the Anza-Borrego area; ${ }^{17}$ however, it was generally unsuccessful. 
Chronologically, the mining boom began with the development of Randsburg as a major gold mining area. The Yellow Aster Mine "glory hole" proved to be deep and exceedingly rich -- one of the two richest ever in the California desert - - and the town around it soon grew into the thousands before the turn of the century. ${ }^{18}$ The Randsburg Railroad arrived in Johannesburg in late 1897; it became a part of the Santa Fe system in 1903. ${ }^{19}$

In the south, the Hedges-Picacho area boomed as wel1. The general area included the American and Golden Dream Mines along with several operations in the Chocolate Mountains; the mines' prosperity also brought increased activity to Picacho, Ogilby and Glamis, supply towns for the area. Picacho's gold was primarily found in loose placers, difficult to extract on a small scale; as a result, a railroad was built in 1902 from the mine to the mill on the Colorado River, where production was more efficient. 20

To the north, the Dale area continued its boom. With the development of the Supply, Los Angeles and Brooklyn Mines, the Dale townsite once again moved east, to what is now known as New Dale. 21 A small amount of mining to the southwest of Dale occurred at the E1 Dorado and nearby mines, 22 and the Copper World Mine/Rosalie mill complex near Clark Mountain was able to grow due to an extension of the railroad to that area in 1899.23 In addition, the 0ld Woman Mountains erupted into a short but feverish boom in 1898 which quickly turned Danby from a placid railroad way-station into a bustling supply center. ${ }^{24}$ 
Other stations along the Santa $\mathrm{Fe}$ were equally fortunate. Blake (now Goffs), the junction point of the California Eastern Railroad, diversified into a major supply center. Fenner benefited from its accessibility to the Columbia Mines, which flared brightly but briefly in 1901-1902. ${ }^{25}$ Vontrigger grew due to nearby copper mines. ${ }^{26}$ Amboy grew because it was a shipping point for the mines around Dale; Bagdad likewise benefited from the Dale success. 27 Ludlow enjoyed its biggest boom ever; not only was it the supply point and railroad junction for the rich, newly discovered Stedman area, but Ludlow also served as the construction camp, from 1904 to 1907 , for the Tonopah and Tidewater Railroad to the north. 28 Lavic had some success from isolated mines and prospects to the south, 29 and Daggett was the wild frontier supply town for the Borate-Calico Mountains area. ${ }^{30}$ The Borate area is of special note. Though Francis M. "Borax" Smith had earlier moved his operations to this area, it stagnated due to Italian competition. 31 The area became more prosperous by the late $1890 \mathrm{~s}$, however, and to make his product more marketable, he finally eliminated his twenty-mule teams with the 1899 construction of the Daggett and Borate Railroad. 32

Some of the most celebrated mines of the period, however, were those in the northern deserts. This area had been generally ignored by miners since the early successes of the $1860 \mathrm{~s}$ and $1870 \mathrm{~s}$, and the spreading out of prospectors, or "pocket hunters," brought discovery of many new claims. 
Ballarat was the focus for many of these discoveries. Though not a mine town itself, it proved a successful supply town for a wide area, chiefly along the west side of the Panamint Range. 33 Located near Post office Spring in 1897, the town had easy access to the Pleasant Canyon (Ratleff) Mines, and enjoyed a roughshod existence for much of its twenty-year life span. 34

Other major camps, settled chiefly in the mid-1900s, included Harrisburg (Aguereberry Camp), Hoveck (Skidoo), Schwab, Lee, and the Greenwater camps. ${ }^{35}$ Most were short-lived (the post office at Schwab, for instance, both opened and closed in 1907), and several were of the trumped-up, boom-town variety. 36

Greenwater, a copper town in the Black Mountains east of Death Valley, was perhaps the prime example of the latter type. Located in late 1904 by agents of wealthy mining interests, the lode provided such eminent figures as industrialist John Brock, copper magnate William Clark, and steel baron Charlie Schwab the opportunity to invest in sure riches. 37 Their respectability brought tens of thousands of investors into support for the various enterprises, which brought to the area thousands of hopeful miners, shopkeepers and other mining-camp characters with varying reputations. On various sites, Greenwater quickly became a respectably sized tent town by early 1907.38 According to one account, it had all the spirit and drive of a city of $100,000^{39}$ but the ore was simply not there. Eventually, financial panic creating stock deflations and ore price dips occurred; together, they were more than the town could withstand. It emptied virtually 
overnight, its occupants drifting to wherever the next real or imagined strike occurred.

Set against the prevailing pattern of short-line railroads and mines developing in concert, the building of the Salt Lake Route from Daggett northeast in 1903-04 emerged as a distinct anomaly. Appearing twenty years after the first trans-desert routes, the railroad had little effect on mining or other local activities. It was originally called the San Pedro, Los Angeles and Salt Lake Railroad, and became part of the Union Pacific system in 1921.40 
1. Steere 1952:11-13

2. Henderson 1978

3. James 1911:361

4. Lantis $1963: 61$

5. Henderson 1978

6. Lantis $1963: 60$

7. Beck and Haase 1974:79

8. Pepper 1972:48-49

9. Steere 1952:20

10. Beck and Haase 1974:79

11. Lantis $1963: 61$

12. Settle 1963:35, 45

13. Myrick 1975:419

14. Dekens 1962:12

15. James 1911:268

16. Bard 1973:75

Lindsay 1973b: 76

17. Lindsay $1973 \mathrm{~b}: 76$

18. Federal Writers' Project 1939a:521

19. Miller 1976:21

20. Myrick $1975: 440$
21. Leadabrand 1966:159

22. James $1911: 483$

23. Bard 1973:72-73

24. Bard 1973:64

25. Bard 1973:65

26. King and Casebier 1976:306

27. Bard 1973:63

28. Myrick 1962

29. Miller $1976: 43-45$

30. Bard 1973:60

31. Federal Writers' Project 1939b:23

33. Paher 1973:40

34. Miller 1976:30

35. Federal Writers' Project 1939b

36. U.S. Post Office Department, various dates

37. Myrick 1962:597

38. Murbarger 1964:16

39. Paher 1973:10

40. Myrick 1962 
CHAPTER 7. THE 1907-1917 PERIOD: MINING IMPACTS CONTINUE WHILE HOMESTEADING DEVELOPS.

The period leading up to World War I was a time of growth on many fronts. Overall, it was an era of steady growth; specific areas, however, experienced only ephemeral growth from mining and homesteading ventures. A large aqueduct and several large canals were built during this time, creating a host of subsidiary land use impacts.

Unquestionably, the largest single event during this time period was the construction of the Owens Valley aqueduct. The 233-mile pipeline had been in the planning stages for some time; ${ }^{1}$ in fact, the covert methods used by the City of Los Angeles in acquiring water rights created a good deal of civil unrest in the Owens Valley, whose agricultural economy was seriously hurt by the water diversion. After acquisition was completed, construction finally began in 1907. The building of the aqueduct took six years; it was considered a remarkable achievement of its day, the first major undertaking of its kind in the country. ${ }^{2}$

Though aqueduct waters did not benefit the desert in the slightest, project construction proved a boon to the area anyway. Pumping stations and construction camps were scattered along the aqueduct, and in order to facilitate transport, a major new railroad line was constructed, roughly paralleling the pipeline route from Mojave north to the vicinity of Lone Pine. ${ }^{3}$ The line was completed in late 1910, creating many trackside "boom towns" at vital transshipment points. ${ }^{4}$ Narka, Little Lake, Haiwee, 
Craft, Neuralia, Ricardo, and others were created from this flurry of activity, and most quietly decayed once the construction activity subsided. ${ }^{5}$ Two large bodies of water - Haiwee and Fairmont Reservoirs -- were created as part of the project. A railroad spur line to an aqueduct station north of Red Rock Canyon was constructed as well, but was removed two years later after that section of the aqueduct was completed. 6

Elsewhere, the most dramatic changes to occur to the desert were caused by homesteading farmers (see Figure 3). Highland valleys and alluvial slopes near playas were the scene of homesteading attempts in many areas, chiefly in well-drained areas above 2500 foot elevation; towns developing within these areas bore such names as El Mirage, Adelanto, Mesaville, Crumville, Chanz, Muroc, Lucerne Valley and Lanfair. ${ }^{7}$ In general, the land was only spottily developed in the areas described, as homesteaders settled on only the more favorable sites; and because of the subsistence nature of the lifestyle, several areas did not have a central town. ${ }^{8}$ Such efforts had mixed success. A few areas, such as Lucerne Valley and Adelanto, have succeeded as agricultural areas to the present; ${ }^{9}$ other areas, such as Muroc, Cronise Valley and Lanfair Valley, continued as producing areas for several decades. 10 Most areas, however, were clearly not suited for farming. Floods, inaccessibility to markets, and lack of water all took their toll -- even the lure of the World War has been cited as a reason ${ }^{11}$ - - and today little besides an interruption in climax vegetation patterns exists to show past efforts. 


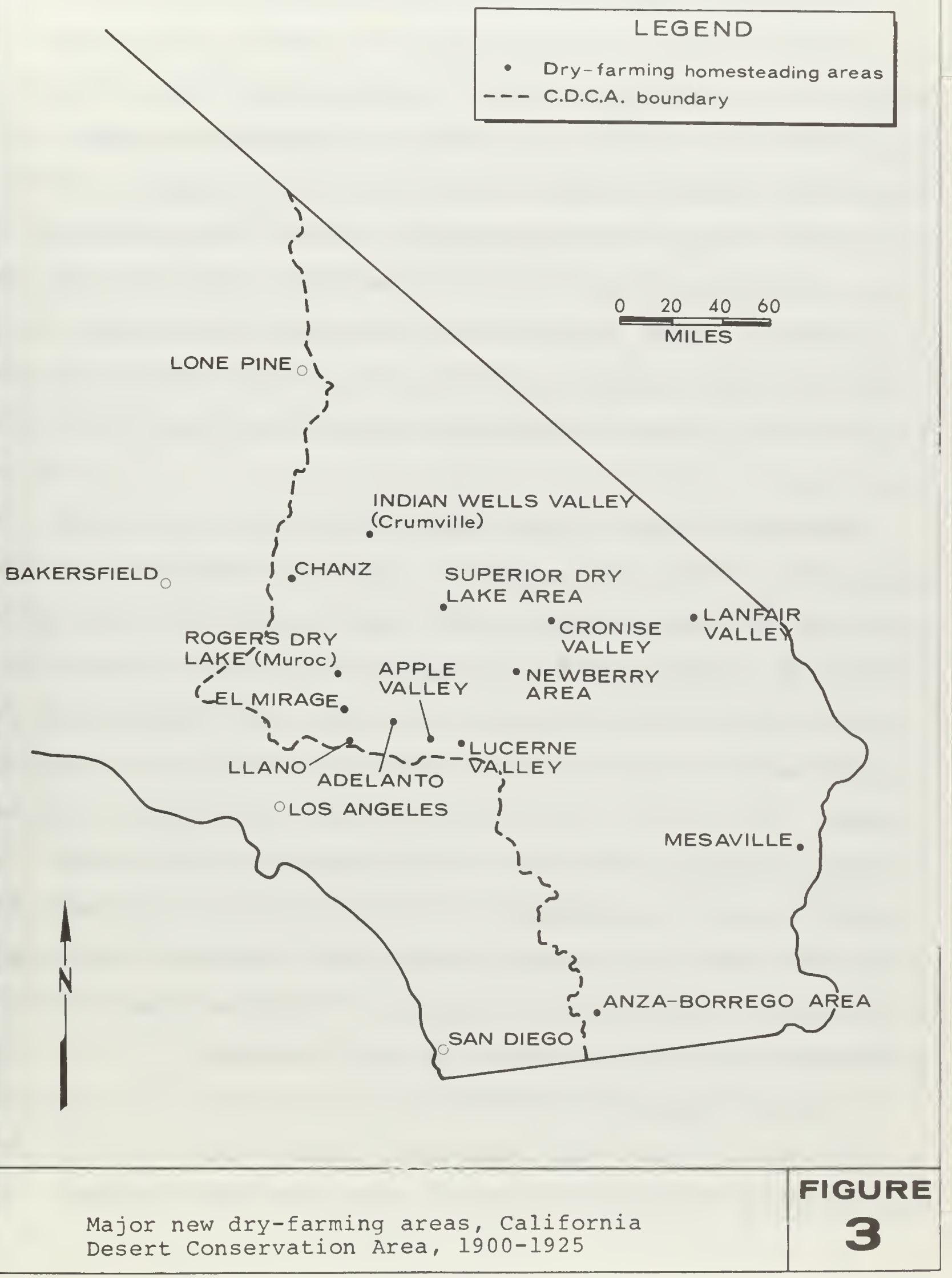


A remarkable example of one community which did not succeed in the long run is that at Llano del Rio, east of present-day Pearblossom. Beginning in 1914, a Utopian colony formed there, organized by Job Harriman, an irrepressible Socialist lawyer. Though the territory appeared clearly unfit for farming - - a colony there in the $1890 \mathrm{~s}$ had likewise failed ${ }^{12}$ - the Utopian colony grew steadily until 1917, at which time over a thousand resided there. Soon, however, internal pressure forced the colony to disband, though lack of water was also a contributing factor. ${ }^{13}$ Most moved to Louisiana; however, the Llano post office has continued to the present day.

More established farming areas, however, had much better success. Due to the introduction of deep wells for pump irrigation in the Antelope Valley, much land previously too dry for tillage was reclaimable. ${ }^{14}$ The Imperial Valley was enjoying large successes as well; with the Colorado River finally under control, much of the rest of the Valley was now able to be cultivated. The northern and eastern portions of the Valley, assisted by the development of the East and West Highline Canals, were opened up during this period. ${ }^{15}$ The towns of Calipatria, Westmorland, Niland, and a host of smaller, more ephemeral communities were created, and by 1917 , the number of irrigated acres there probably exceeded eighty percent of today's acreage. ${ }^{16}$

Irrigable areas along the Colorado River fared equally well. The Bard Valley, near Yuma, came under large-scale irrigation at this time due to the construction of the weir called Laguna 
Dam. ${ }^{17}$ Calzona, along the newly-built line from Cadiz to Parker, was the site of a lively boom between 1909 and $1914 ;^{18}$ though much of the activity came from railroad construction activity and local mines, date orchards and other crops were also attempted without success. The Palo Verde Valley also came into prominence at this time, owing to the construction of a weir (Palo Verde Dam) and irrigation system originating northeast of Blythe. Blythe, Rannells and Fertilla -- particularly Blythe -- sprang into prominence at this time. Flooding, however, was a problem, limiting development until the construction of Boulder Dam in the mid-1930s. 19

Though more controlled, mining continued as an important sector of the desert economy. The days of the freewheeling prospector were beginning to fade; though many new prospects were found in this period, most were small and were actually profitable for only a short time. Instead, corporate entities took over, sometimes in precious metal production but also in borax, salt and other non-precious minerals.

The northern desert continued to be a major focus of activity. Skidoo, emptied by the Panic of 1907 , was quickly reborn when the Skidoo Mines Company was formed, and with the help of a 23-mile-long water pipeline from the Telescope Peak area, lasted until 1917. ${ }^{20}$ The Keane Wonder Mine, north of Furnace Creek, and the Lila C (old Ryan) borax mine became active at this time, as did the Gunsight and Noonday Mines, major mines of an earlier day. Smaller camps were located along the east side of Death Valley, and mills for processing the ores were established at 
water sources near the valley floor. ${ }^{21}$ Short-lived camps were also established at Avawatz and Crackerjack around 1908; the latter site featured a full-sized townsite. ${ }^{22}$ The Tonopah and Tidewater Railroad had been built from Ludlow up to this area in 1906-07, specifically to develop the minerals there and in Nevada; however, the mines had become worked so much by the late completion date that the line was immediately dubbed as "the train that went from nowhere to nowhere." 23 Much extra business was gained from the line's presence, however, and many mines owed their presence to the T\&T. ${ }^{24}$ The Acme, Gunsight and Noonday Mines even had spur 1 ines to the mine properties. 25

Mines were also active in other areas. The Dale gold mines continued to be prominent until World War $I$, and were operated by the United Greenwater Company in their final years. ${ }^{26}$ The Orange Blossom Mine, near Bagdad, had a short but feverish boom shortly after 1907.27 The camp at Hedges was taken over by The United Mines Company about 1910; taking its name from an acronym for the company, the town of Tumco operated until about World War I. ${ }^{28}$ Stedman, a camp situated at the Bagdad Chase Mines, was also a corporate venture. Perhaps the richest mine in the entire desert, the town was notable for having its houses widely spaced as a fire prevention measure. It was also somewhat staid, considering its economic base, doubtless caused in part by the total prohibition against liquor in the camp. 29

Borax continued to be a major product of the desert. The deposits at Borate began to give out about 1907; therefore, 
"Borax" Smith moved his operations to the Lila C. Mine near Death Valley Junction. The town that grew up at the mine was called Ryan. The ore was produced in commercial quantities until 1915, when operations were moved west to a new site. ${ }^{30}$ Named New Ryan, the operation lasted until 1927.31 Both "Old Ryan" and "New Ryan" were accessible by rail; also, the processing plant at New Ryan had an additional seven miles of baby-gauged track that connected it with its mines. 32

Locations for mines of other than precious metals were scattered throughout the desert. Perhaps the largest of these were the operations at Searles Lake, which resumed in 1913 after almost a twenty-year lapse. ${ }^{33}$ At the time, it was primarily a borax operation, but soon began producing potash, soda ash, and other compounds. ${ }^{34}$ A company-owned railroad was built to the area the same year. ${ }^{35}$ Gypsum, also a large producer at this time, was also active near Amboy and Saltdale. ${ }^{36}$

Salt also became a more important desert commodity. One new operation opened in Saline Valley, an area which had been almost entirely ignored up to this time; it became the site for a salt works in 1913. ${ }^{37}$ Evaporation areas were set up on the lake edge, and using a tramway going over the Inyo Mountains to near Swansea, various companies kept up intermittent operations at the lake until 1930. It was never a large-scale operation, however. Salt also began to be extracted from Danby Dry Lake by 1910, where operations were to continue for several decades. 38 
Finally, major symbolic strides were being made in the development of a road system. Hardly noticeable prior to this time, a few roads began to be improved across new areas of the desert. Most early roads followed the railroad tracks; in other areas, previous wagon roads were used. ${ }^{39}$ Futuristic 1ong-distance highways, such as the "Ocean to Ocean Highway" and "The Midland Trail" began to appear by 1915 , but their major value at first was for directional purposes only. Orientation was also helped out by county-sponsored signposts; begun in San Diego County as early as 1895 , they became predominant by this period. 40 These signs were soon superseded, however, by the more complete signs provided by the Automobile Club of Southern California, whose members were among the few early motorists adventurous enough to tour into the desert.

Road conditions in the desert varied widely. Contrary to some reports, most roads were not able to be easily, conveniently traveled, though road grading became more commonplace by this time. ${ }^{41}$ To traverse sandy areas, roads of wooden planks were used; a first appeared on the road between Mesaville and Blythe Junction (Rice), 42 and shortly afterwards another crossed the Algodones Sand Dunes near Yuma. ${ }^{43}$ In other sandy areas, such as near Dos Palmas, straw was laid in the ruts, though carelessly discarded cigarettes occasionally burned up the road. 44 
1. Federal Writers' Project 1939a:518

2. Lantis $1963: 26$

3. Turner $1964: 6$

4. Myrick 1962:208

5. AAUW 1953:40

6. Myrick 1962:205

7. USGS Quadrangles, various dates

8. Starry 1973:64 Bard 1973:94-99

9. Goulding 1948

10. Johnston 1940:12

11. Otis $1977: 114$

12. Settle 1963:36

13. Leadabrand $1966: 38$

14. Settle 1963:63

15. ACSC, "Imperial County," various dates

16. Henderson 1978

17. Myrick $1975: 440$

18. Dekens 1962:50

19. Dekens 1962:13

20. Paher 1973:37

21. Paher 1973, various pages

22. Miller 1976:49
23. Myrick 1962

24. Strong $1975: 22$

25. Myrick 1962

26. Miller $1968: 21,51$

27. Bard 1973:80

28. Johnston 1928:18

29. Myrick 1962:835

30. Paher 1973:14

31. Federal Writers' Project 1939b:23

32. Myrick 1962

33. Miller 1976:27

34. Wynn 1963:238

35. Myrick 1962:798

36. Ver Planck 1952

37. Turner 1964:6-7

38. Ver Planck 1958

39. Bard 1973:88-89

40. James $1911: 332$

41. Bard 1973:87

42. Dekens 1962:55

43. Edwards $1969: 250$

44. Pepper 1972:90 
CHAPTER 8. THE 1917-1925 PERIOD:

HIGHWAY SETTLEMENTS DEVELOP;

HOMESTEADING AND OTHER

ACTIVITIES SLOWLY DECLINE.

In this period, major new activity was brought about by the extension of the road system. It was also a period of very active (though not generally expanding) railroad activity. Mining declined, as a rule, as did homesteading, though notable growth areas existed in both economies.

During this period, roads came to be recognized as a major transportation mode. Therefore, the road system began to develop. Though most roads began along the side of railroad tracks, or between waterholes, they often strayed away from them when the road was improved. The Cajon Pass Road is a good example; it forsook the Mojave River Valley and Hesperia for a more direct route across Baldy Mesa in 1922. ${ }^{1}$ Because traffic was still generally light, very few (if any) new locations were established strictly to service highway traffic. More commonly, feed or blacksmith shops or general stores converted to service stations, and in some cases, such as Danby, an alternate set of buildings was constructed to service the highway near an existing railroad town. 2

While highways were gaining in importance, this was not at the expense of other transportation modes. Both national and area railroads were at the height of their popularity: They carried more traffic over more miles of track than at any time in their history. The opening of the San Diego and Arizona (later 
San Diego and Arizona Eastern) Railroad between San Diego and El Centro in 1919 proved to be the last major route addition in the desert, ${ }^{3}$ while the abandonment of the Goffs-Barnwell branch in 1923 proved to be the first of many in coming years. ${ }^{4}$ While not causally related, railroad maintenance- and way-stations were also at their peak at this time, creating a solid line of railroad "settlements" at 5-to-7-mile intervals over much of the desert. ${ }^{5}$ While these sidings were usually small (with between two and ten inhabitants) and not dependent upon the surrounding desert for their needs, their sheer numbers -- perhaps 150 to 200 of them during this period ${ }^{6}$-. made them a consistently important part of the desert's land use and demography up to the Second World War.

Mining continued, but with few exceptions, the feverish prospecting days were gone. Extraction of borax increased along Searles Lake, and mines continued strong at New Ryan and the Tecopa area. The Goldstone-Goldbridge area boomed for the third and largest time in the early 1920 s under a corporate structure, ${ }^{7}$ but elsewhere, few new strikes were reported; in fact several operations, such as those at Panamint, Calico and Cerro Gordo, reworked old deposits. World War I did bring some demand for new minerals; accordingly, the Atolia area boomed from its large tungsten deposits, ${ }^{8}$ and antimony made the much-less-accessible Wildrose area bloom until the end of the War. ${ }^{9}$ The Copper World Mine on Clark Mountain also was active at this time. ${ }^{10}$ Salt extraction expanded; it remained active at its previous locations, 
and new areas opened up on the west and north sides of Bristol Dry Lake and at Bush, on the east edge of Dale Dry Lake east of Twentynine Palms. ${ }^{11}$ Cement became important in the Victorville and Oro Grande areas; ${ }^{12}$ it remains so today.

The single example of a feverish, pioneer-style mining town existed on the slopes of Red Mountain, in extreme western San Bernardino County east of Johannesburg. Here, a large vein of silver ore was discovered in 1919 in an area that had been combed by prospectors for decades, and a series of small mining camps soon appeared. Main ones were called Hampton, Osdick, and In City (called so, according to one account, because of a caretaker who put up a sign saying "always in," and an itinerant prospector who rejoined with the sign "seldom in"). The post office, when established, was called Osdick, but due to intercamp rivalry was eventually renamed Red Mountain. 13

The period proved a fruitful one for oddly mechanized attempts at mineral extraction. A tramway was built up the Yellow Grade to Cerro Gordo to assist with the reworking of minerals there, ${ }^{14}$ and a thirty-mile monorail was constructed in 1923 to extract epsom salts from the eastern slopes of Brown Mountain. Though the Cerro Gordo tramway operated sporadically for the better part of two decades, the monorail was less successful. ${ }^{15}$ Mechanical problems dogged the operation from the start; shortly after those were cleared up, the material was found to be too dusty for commercial use, and the project was abandoned. 16 
Homesteading decreased dramatically during this period. As explained before, the teens were difficult years for homesteaders, and by the early 1920s, acreage had either dramatically decreased from former levels or was eliminated entirely. ${ }^{17}$

In other areas, farming generally succeeded. The Kingston area, in northeast San Bernardino County, was opened up, and due to successful experiments at the Indio Experimental Station, date palms were introduced to several small areas in the Coachella Valley. 18

Coupled with greater access to the desert via auto and train travel, persons began to show greater appreciation for the desert during this period. Throughout the 19 th century, this had not been the case; non-residents had usually held the desert with disdain. Around the turn of the century, however, several sensitive authors, among them John C. Van Dyke, George Wharton James, Arthur Burdick, and Mary Austin, began to describe the desert as a delicate, beautiful place. ${ }^{19}$ Their books were well-received; but it was not until the 1920s, when the desert was more accessible, that outsiders began to visit the desert for recreation. As a result, resorts began to flourish there. Palm Springs and Victorville were perhaps the two major early foci for this activity, but Twentynine Palms, Coso Hot Springs, the Phelan area and La Quinta all became known as well. 20

Victorville in the 1920 s was just beginning to emerge from its previous tough mining and railroad days. Though more sedate than before, its "western" appearance, coupled with its proximity 
to Hollywood, made it attractive as an early movie-colony hideaway before Palm Springs became de rigeur. To fit the image, the town remained old-fashioned in appearance for many years; to embellish its atmosphere, it had guest ranches, saloons, rodeos and western events. 21

Palm Springs, on the other hand, was as refined and dignified as Victorville was earthy. It had been primarily a resort for consumptives (tuberculosis victims), asthmatics, and others who had real or imagined health ailments until the World War; 22 afterwards, the town began to attract a growing permanent population. 23 The warm springs, around which the Cahuilla village and early hotels had been located, became less important, and the warm winter weather and gracious small-town hospitality soon became a well-known product. ${ }^{24}$ Palm Springs was still in its infancy in the early 1920s, but its development pattern had been set by then. 25 It is also important to note that the first real attempts at large-public scale preservation in the California desert were made at this time; in 1922 , a national monument for the Palm Canyon area was seriously considered. The bill, probably inspired by early Palm Springs residents, was even passed by Congress. However, a stipulation was placed on the bill requiring the consent of the Agua Caliente Indian band. Such consent, however, was refused, and it was to be another ten years before the first designated parkland was created. ${ }^{26}$ In the same area, sentiment grew for the preservation of the local bighorn sheep population; Game Refuge 4D, the first controlled land-use area in the desert, was implemented in 1917.27 
1. Otis $1977: 130$

2. Bard 1973:85-86

3. Henderson 1978

4. Mojave River Valley Museum Association 1977

5. NRPC 1929

6. Khruttschnitt 1978

7. Farnsworth $1965: 47-60$

8. Wynn $1963: 228$

9. Paher $1973: 38$

10. Bard 1973:92

11. Ver Planck: 1958

12. Myrick 1962

13. Miller $1976: 23$

14. Turner 1964:8

15. Myrick 1962
16. Federal Writers' Project 1939b:63

17. ACSC maps, various areas and dates

18. Steere 1952:59

19. Edwards 1969:14

20. ACSC maps, various areas and dates

21. Federal Writers' Project 1939a:614

22. Roske 1968:46 James 1911:282

23. Chase 1920:38

24. Federal Writers' Project 1939a:628

25. Hussar $1977:$ E2

26. Rinaldi 1978

27. Nathenson 1978 
CHAPTER 9. THE 1925-1932 PERIOD: HIGHWAY

SETTLEMENTS DEVELOP, WHILE THE AMENITIES GAIN MORE IMPORTANCE AS A DESERT ATTRACTION.

During the late 1920 s and early 1930s, several broad movements were taking place. The development of a series of highwayoriented settlements was perhaps foremost among these; in addition, resorts and settlements were continuing to grow from their appeal to the sun, warmth and other positive desert qualities.

Though still at a relatively small scale, desert auto traffic increased dramatically during the late 1920s. ${ }^{1}$ With increased leisure time, generally increasing income and more dependable automobiles, people began to go automobile touring. To meet the demand, highways were improved and way stations became established to cater to the tourist trade. Therefore, perhaps fifteen to twenty "settlements" were established in the desert during this period, among them Miller's Corner, Mojave Water Camp, Paso Alto Station and Midway Wel1. ${ }^{2}$ Simple but functional, most were a cluster of buildings, containing a service station, and usually a lunch room. Also included was a tourist court with several small, detached cabins; because many motorists drove at night due to daytime heat, cabins could often be used twice each day. ${ }^{3}$ Most existing communities also added services during this period to meet the demands of motorists; hotels near the railroad station continued to provide lodging.

Public recreation on the desert expanded further as accessibility increased. Cathedral City and other nearby areas were 
settled largely by those who enjoyed desert living, and Palm Springs grew quickly as the Hollywood colony began to discover it. Small resorts were established in Morongo Valley, and at the top of Mountain Springs grade near the Mexican border. ${ }^{4}$ Death Valley also became a major tourist lure at this time; the Stovepipe Wells Hotel was opened in 1926, reached by a toll road over Townes Pass, and a year later, the Pacific Coast Borax Company opened up its Inn and Ranch at Furnace Creek. ${ }^{5}$ Gun clubs also grew into prominence, especially around the Salton Sea and Rosamond Dry Lake; those around the Salton Sea are of particular note because the hunting there helped bring about the desert's first federal wildlife refuge, which was larger than the existing one. 6 Due to rising levels of the inland sea, however, most of the clubs there were eventually flooded, and much of the present wildlife refuge has been left well away from shore.

Agricultural acreage changed little during this period. Due to more sophisticated farming methods, good farmland became more productive, while marginal and sub-marginal land was generally discarded. Homesteaders, partly because of an ugly series of incidents with local ranchers, finally disappeared from the Lanfair Valley, ${ }^{7}$ while in other areas, particularly around Borrego Springs, a few new farms were forming. ${ }^{8}$

Mining also met with mixed success. As in previous periods, precious metal production generally fared worse than borax, cement, salt, and other non-precious commodities. New gypsum plants were built in the mid-1920s at Midland and at Plaster 
City; at the latter, a company-owned railroad was built northwest from there to haul the gypsite necessary for its manufacture. ${ }^{9}$ Around Searles Lake, the American Trona company became the American Potash and Chemical Company in 1926, and further growth ensued. 10 Another significant change occurred in 1928, when the Pacific Coast Borax Company decided to move its facilities from New Ryan southwest to Kramer, near the Kern-San Bernardino County line. The existence of a deposit of colemanite (borax-bearing ore) had been known as early as 1913, but it was not until extensive drilling and surveying had been completed that the Pacific Coast Borax facilities were relocated. ${ }^{11}$

Precious mining, as mentioned before, continued to deteriorate. Although prospectors still combed the hills, few new discoveries were made, and methods for mineral exploration and recovery became increasingly mechanized and scientific.

A notable exception to this general decline occurred at Leadfield, where a feverish if short-lived boom took place. The town was the brainchild of promoter C. C. Julian, and its development followed the pattern preceded by Greenwater and other camps influenced more by stock purchases than ore discoveries. ${ }^{12}$ The activity occurred in 1926. Lead in some quantity was found in Titus Canyon, east of Death Valley, and with the help of Julian, an accomplished stock manipulator, the town was advertised widely. A special train was brought from Los Angeles up to nearby Beatty, and with the help of talented pitchmen leading the throng to well-salted claims, the success of the community was assured. 
The town grew to several hundred by mid-summer, and sported its own newspaper among its many businesses. ${ }^{13}$ However, it soon became apparent that the ore was of a grade too low for commercial production. Among the last businesses to go was the post office; when it closed in January 1927, only one person remained. 
1. Bard 1973:85-86

2. ACSC maps, various areas and dates

3. Bard 1973:92, 103-104

4. ACSC maps, various areas and dates

5. Paher 1973:7, 35

6. ACSC, "Imperial County," 1938

7. King and Casebier 1976:320

8. Lindsay $1973 \mathrm{~b}: 102$

9. Ver Planck 1958

10. Leadabrand $1969: 37$

11. Miller 1976:41

12. Weight $1977: 35$

13. Paher 1973:33 
CHAPTER 10. THE 1932-1940 PERIOD:

GOVERNMENT WORK PROJECTS

AND A MINING REVIVAL

IMPACT THE DESERT;

PARKLANDS APPEAR.

In this period, one of the most active desert periods ever, the character of the desert changed significantly. Highway traffic, roads and towns increased; railroad mileage and traffic, on the other hand, atrophied. New mines were discovered and old ones reworked, and due to a variety of government work projects (in addition to road-building), productivity and activity were brought to areas previously ignored by man. Large areas were also set aside as parklands, and the military began to show interest in the desert for the first time since the $1860 \mathrm{~s}$.

In terms of its areal impact (or non-impact) on the desert, the establishment of three large parks was the most significant event of the 1932-40 period. The area surrounding Borrego Valley was technically the first of these to be preserved; though the preservation of parts of that area was seriously proposed as early as 1926, legal protection of that area did not occur until the early 1930s. In the earliest formal withdrawal, the Borrego Palms Desert State Park was set aside in 1932. The rest of the early park boundaries were formalized in the next few years, and it was renamed Anza Desert State Park in 1938. The boundaries at that time included much of the Borrego Valley, now in private hands; today's park boundaries are the result of a 1939 land trade, worked out to extend the park boundaries while simultaneously 
providing agricultural interests with land for orchards and field crops. 1

At over two million acres, Death Valley is the largest national monument in the California desert -- and for that matter, the largest in the coterminous United States. It was signed into law in February of 1933, in the lame-duck days of the Hoover administration, and was enlarged to approximately its present size in $1937 .^{2}$ The proclamation of the monument barely affected activities in the area at all; existing facilities and residences remained open and in private hands, and unlike most other Monuments, mining continued to be allowed within its boundaries. 3

Joshua Tree was the final major parkland to be preserved during this period. Over 800,000 acres in extent, it was dedicated in 1936, although the area had been withdrawn from settlement three years before. The monument was largely the result of the untiring efforts of Mrs. Albert Sherman Hoyt. An active South Pasadena resident interested in the protection of the Joshua tree (yucca brevifolia), she formed the International Desert Protective League in the 1920 s and marshalled support for a preserve with many influential local citizens. Creation of the monument came about only after her repeated pleading with Interior Secretary Harold Ickes; the acreage granted to the park was a compromise from a previously-proposed parcel that had extended south to the Salton Sea. ${ }^{4}$ As at Death Valley, livelihood patterns were encumbered very little with Monument designation; in fact, 
the Monuments as an attractive force proved to be a boon to nearby retail business. Visitation of the parks, however, remained relatively low until after World War II (see Figure 4). The mid-to-late 1930 s also proved to be a very strong roadbuilding period. Two of the major east-west highways -U.S. 66 (now Interstate 40) and U.S. 91 (now Interstate 15) -were paved in $1932,{ }^{5}$ and most of the other major desert roads were paved shortly afterwards. Thus, by the time U.S. 60-70 (later to become Interstate 10 ) was paved from Indio to Blythe about 1936, most of the present-day road pattern (except for freeways) had been completed.

Because of the new ease of access into the desert, several new way stations were established on each of the newly-paved roads. Established towns added new services as well, particularly those (such as Baker) on major new tourist routes and junctions. Much of the traffic on the new roads travelled to and from Trans-Missipppi points; closer to home, dam workers and recreationists to Boulder (later Hoover) Dam and Lake Mead also attracted a large and growing number of visitors after the mid1930 s. $^{6}$

While road mileage boomed, railroads were steadily losing business. Because most of the stations in the desert had been set up for maintenance purposes, their existence was not related to traffic and they were thus unaffected by this loss. Coincidental loss of mining revenues, however, forced several segments of Iine to be abandoned. Specifically, the spur to Randsburg, as 


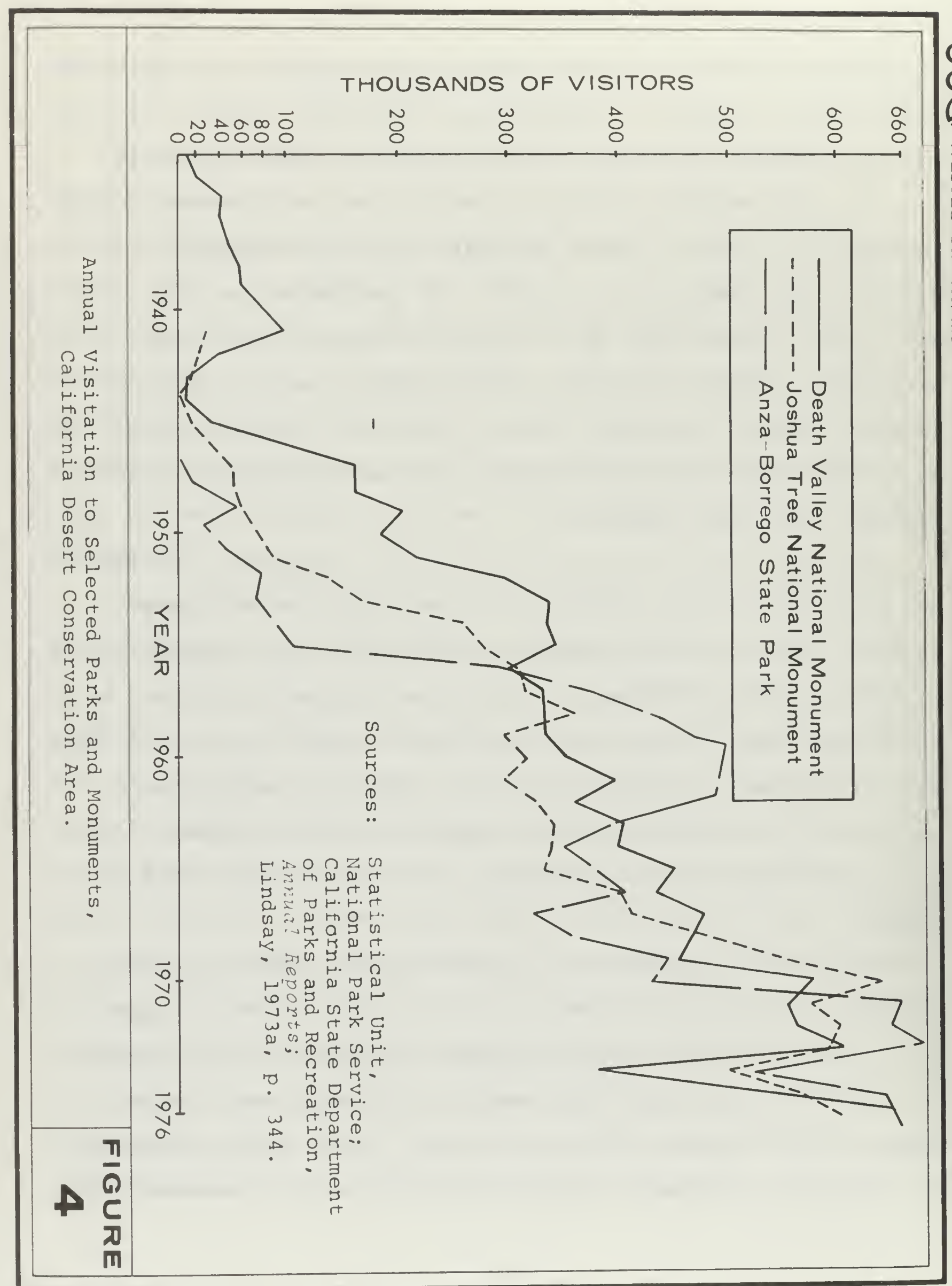


well as the Tonopah and Tidewater (T\&T) route from Ludlow to Crucero, was abandoned in 1933. The Stedman spur line had been abandoned during the previous year, and the remainder of the T\&T, from Crucero up into Nevada, operated for the last time in 1940.7 Mining enjoyed a welcome resurgence. Though sources differ here, the Great Depression seems to have encouraged a rebirth in precious-metal mining. Old mines were reworked, oftentimes on an almost primitive basis, and exploration was again awakened for new lodes and placers. ${ }^{8}$ As a result, a great deal of small-scale mining occurred during the mid-to-late $1930 \mathrm{~s},{ }^{9}$ and a major new gold rush occurred near Mojave. Its locale was Soledad Mountain; the mine was the Golden Queen, a corporate operation. 10 The settlements of Gold Town and Reefer City grew up just north of the mountain; the latter was so named because its residential and business buildings consisted almost entirely of railroad refrigerator cars, doubtless brought over from the Southern Pacific scrapyard a few miles to the east. ${ }^{11}$ The mine was active only a few years, though the settlement below probably continued to last awhile longer.

The effects of the depression, however, were felt far beyond the small mining resurgence. Though Civilian Conservation Corps camps did not exist in the desert, several large water projects were constructed with the inexpensive labor available, and as well, a significant number of people probably migrated to the desert to escape the depressed conditions of the cities. ${ }^{12}$ Their numbers may never be known, but several examples exist of persons 
who migrated to abandoned towns and buildings to eke out a "beans and rabbit-meat" existence as an alternative to the soup lines of the cities. Some of these persons still live in the desert today. 13

In the southern desert, construction of two major water projects enlivened what were otherwise fairly static conditions. The projects included the construction of the Metropolitan Water District Aqueduct from the Colorado River to the Los Angeles area in 1934-41, and the building of the All-American and Coachella Canals in 1936-40 as part of the Hoover Dam-Colorado River Project. 14

The All-American Canal was a project designed to circumvent the problems which the earlier Imperial and Alamo Canals had caused. Unlike the earlier canal system, the All-American Canal was located entirely in the United States, and was built in a concrete-lined channel away from natural drainageways. As part of the project, the Imperial Dam was built in 1935, and the canal itself was under construction from 1936 to 1940. The plan required the creation of several large settling ponds near the Colorado River to remove silt; in addition, several hydroelectric power plants were constructed at critical waterfall points along the route. ${ }^{15}$ The Coachella Canal was an offshoot of the AllAmerican Canal, designed to deliver water to the Coachella Valley. The All-American Canal was completed by 1940, but due to wartime delays, the Coachella Valley did not receive canal water until 1948. ${ }^{16}$ Winterhaven and Calexico served as construction camps for the projects. 17 
The Metropolitan Water District (MWD) project was even larger in scale than the Colorado River project aqueducts. Two hundred and forty-two miles long, it was built to deliver water from the Colorado River to Lake Mathews, near Riverside; from there it travelled by several smaller lines to various cities in the Los Angeles metropolitan area. Like the Owens Valley project, it brought no water to desert points themselves. The project called for the crossing of several mountain ranges; therefore, in addition to the two hundred-odd miles of open and closed aqueduct in the project, four pumping plants were built in the desert alone. The project also required the construction of Parker Dam, near the easternmost point in the state, and several long transmission lines, among the first to be constructed in the desert. ${ }^{18}$

Though the MWD aqueduct was authorized in 1933, construction did not really begin in the desert until 1934, when work began on Parker Dam. Construction along the entire route was soon flourishing. Cross Roads and Rice were busy as major supply points to the aqueduct, and Berdoo Camp, on the Coachella Valley side of the Little San Bernardino Mountains, was a large headquarters camp for the construction work going on in that area. The Coachella Valley section of the aqueduct was almost entirely underground; to accomplish the difficult task of boring numerous tunnels, smaller camps located in the major canyons of the Little San Bernardino Mountains were set up as construction sites. 19

The MWD project brought more than water across the desert. In addition to the high-voltage transmission lines mentioned 
previously, aqueduct construction also brought underground gas pipelines and roads. ${ }^{20}$ Pumping plants were located at Parker Dam, Iron Mountain, Eagle Mountain and Hayfield, and remain there today with a small but permanent number of maintenance personnel. ${ }^{21}$ Finally, the military began to show renewed interest in the desert. With the advent of aircraft as a major tactical weapon, the desert's lack of vegetation and high visibility became distinct advantages. Accordingly, the Army set up the Muroc Bombing and Gunnery Range on the east side of Rogers Dry Lake in $1933 ;^{22}$ in time, it was to evolve into Edwards Air Force Base. 
1. Lindsay $1973 \mathrm{~b}: 89-97$

2. Rinaldi 1977

3. Cook 1967a:7

4. O'Neal 1957:120

5. Bard 1973:113

6. U.S. Department of the Interior $1904-40$

7. Myrick 1962:593, 798

8. Leadabrand 1966:107

King and Casebier 1976:306

9. Federal Writers' Project 1939a:544

10. Treolar 1975:36

11. Federal Writers' Project 1939a:545 ACSC "Kern County," various dates

12. Bard 1973:108-109

13. King and Casebier 1976:323

14. Lantis $1963: 38,61,163$

15. Lantis 1963:61

16. Lantis 1963:61

17. Federal Writers' Project 1939a:637

Steere 1952:27

18. Weymouth 1939

19. Weymouth 1939:55

20. Bard 1973:110

21. ACSC "Riverside County," various dates

22. Leadabrand $1966: 62$ 
CHAPTER 11. THE 1940-1945 PERIOD:

THE MILITARY IMPACTS THE LAND;

THE DESERT IS FURTHER CLASSI -

FIED, WHILE SOME NEW MINING

IMPACTS OCCUR.

During World War II and the period immediately preceding it, the military and war effort exerted almost total control over the affairs of the California desert, just as it did over most of the rest of the country. In the desert, however, there existed vast land use impacts as well, as the military took advantage of the sun, dryness and unique desert terrain.

As mentioned previously, the Army Air Corps had realized the advantages of the desert several years before when the Muroc Bombing and Gunnery Range was established. By 1940, however, preparations were being made for war, and, for training purposes, two large tracts were opened that year. One was a greatly expanded gunnery range in the Rogers Dry Lake-Muroc area, while the other was the Camp Dunlap Aerial Gunnery Range, in the Chocolate Mountains east of the Salton Sea. ${ }^{1}$ In connection with the Muroc facility, a large tract of land northeast of Barstow was set aside that same year; called the Mojave Army Antiaircraft Range, it was later renamed Camp Irwin. ${ }^{2}$ The Army Air Corps likewise took advantage of the desert conditions in the Twentynine Palms area, and in 1941 established a glider training base which they named Condor Field. 3

Significant as these prewar training-oriented bases were, they comprise only part of the military's impact on the land 
in the early 1940s. War broke out in December of 1941, and with war came the necessity for quickly training a large number of men for combat readiness.

Military planners knew that, because of the Axis occupation of North Africa, the Allied forces had to be trained in the art of desert warfare. Many areas in the California desert closely resembled North Africa's desert conditions-- in fact, the motionpicture industry had consistently used various parts of it as a backdrop for its "Arabian" desert movies. Therefore, a huge sector of the eastern California desert was given over to this purpose. Called the Desert Training Center (DTC), the area encompassed all land between Searchlight, Nevada and Yuma, Arizona, and between Desert Center and the Colorado River. ${ }^{4}$ Not all of this area was used for the army's training exercises, but judging by the jeep and halftrack marks still visible, much of the non-mountainous area in the eastern desert was the site of some military maneuvers. Operations, of course, had a marked negative effect upon the slow-growing perennial desert vegetation, and the planned military destruction of many desert waterholes resulted in severe effects upon desert wildlife. In addition to DTC operations, several existing bases west of the DTC, such as Camp Irwin and the basin north of Twentynine Palms, were also employed as armored-division training sites. 5

The whole operation was under the auspices of the Armored Division of the Army, commanded by General George C. Patton. A man who oftentimes dispensed with personal and organizational 
protocol in order to accomplish his goals, he is given a large share of the credit in preparing his troops for the North African invasion in a remarkably short time. He chose as headquarters camp a site just south of the Iron Mountain Pumping Plant, and established several subsidiary camps. They included Camp Young (between Indio and Desert Center), Camps Granite and Coxcomb (between Rice and Desert Center), Camp Essex (near Danby), Camp Ibis (near present-day Searchlight Junction), and other locations for POW's and deserters.6 Patton's men used the Clipper, Dead and Eagle Mountains as artillery ranges, ${ }^{7}$ and before the camps in the eastern desert were set up, his forces used the Anza-Borrego desert, particularly the Borrego Badlands around Font's Point, as the scene for weekend tank-training maneuvers. ${ }^{8}$

The war brought on the demand for many other facilities. For pilot training and other functions, Air Force bases or Army air fields were established near Daggett, Victorville, Blythe, and Rice, ${ }^{9}$ and war materials were distributed through supply depots located at Nebo (near Barstow) and near Yermo. ${ }^{10}$ Additional gunnery ranges, as needed, were created northwest of both Twentynine Palms and Plaster City, ${ }^{11}$ and at sites east of the Chocolate Mountains. The war also brought about the need for weaponstesting facilities. The 750,000-acre Naval Ordinance Test Station (NOTS) was therefore established in 1943, transforming the southern Indian Wells Valley into an instant urban complex, as 16,000 construction workers and base personnel descended upon the area. ${ }^{12}$ 
Massive as the various military operations were in size of their impact, most were relatively short-lived. Patton's forces were in large part gone by early 1943, and the various Air Force bases eventually stopped operations as well, though most continued to function for a few years after the war. Camp Irwin, with a peak wartime population of 17,000 , was deactivated in $1944 ;^{13}$ however, NOTS and most of the gunnery ranges continued to be used due to ever-increasing sophistication in weaponry.

In the non-military sector of the economy, it was a relatively quiet period. Predictably, some of the new activity was related to military needs. Much of the desert economy stagnated, however, due to wartime travel and use restrictions.

Aside from the relatively permanent extraction industries on the desert, such as salt, borax, limestone and allied chemicals, traditional mining operations were generally inactive during the World War II period, and some mines were not allowed to operate. The war effort, however, encouraged the production of iron and other needed raw materials. As a result, favorable government price supports brought about tin, lead and zinc mining in the Mountain Pass area; ${ }^{14}$ a mill was established near Windmill Station to process these ores. The Bagdad-Chase Mines, south of Ludlow, also continued to operate at this time, among the few gold mines in the country allowed to operate during the war years. An active but short-lived calcite mine also operated in the Borrego Badlands during the war. 15 
Far larger in scale for the desert economy was the Kaiser Vulcan Mine. An iron mine near Kelso, it was opened in conjunction with a smelter in Kelso and a mill near Fontana to provide the country with dependable inland steel production on the west coast. ${ }^{16}$ Liberally supported by the government, the mine and smelter produced prodigiously through the war years, creating a road, a large mining and smelting complex and a town of three thousand people at Kelso in the process. A sizeable population also existed at the mine site itself. ${ }^{17}$

Agricultural development was mixed. The Harper Lake area, an alfalfa-growing area northwest of Barstow, became prominent at this time, utilizing deep wells for its water. ${ }^{18}$ Elsewhere, as in the Anza-Borrego area, wartime gas restrictions curtailed pumping and limited production to largely subsistence levels. ${ }^{19}$ The Needles area also lost some of its farming but for an entirely different reason; due to the rising level of Lake Havasu, much of the irrigable farmland on the California side of the river was inundated. 20

Urban growth occurred despite the war, particularly in the Palm Springs area. The town was by this time quite well-known; described in a contemporary work as "one of the newest playgrounds of rich America," 21 it attracted visitors and residents not only to itself but to nearby communities. La Quinta, a town "as uneffusive as Palm Springs is flamboyant," 22 grew quickly during the war as a restful retreat for those of some means, while Desert Hot Springs, conversely described as "a poor man's Palm 
Springs," 23 grew during the same period. Other nearby towns saw comparable growth. 
1. Morain 1963:24

2. ACSC "San Bernardino County," various dates

3. O'Neal $1957: 136-137$

4. Meller 1946

Beck and Haase 1974:86

5. Cook 1967d:30

6. Bard 1973:125, 139

Me1ler 1946

7. Bard 1973:138

King and Casebier 1976:324

Miller 1968:64

8. Parker $1957: 84$

9. Otis $1977: 128$

USGS maps, various areas and dates

10. Bard 1973:108

11. O'Ireal 1957:137

Lindsay 1973b:100

12. AAUW 1953:29

13. Lantis $1963: 52$

14. Bard 1973:109

15. Lindsay $1973 \mathrm{~b}: 103$

16. Lantis 1963:45

17. Bard 1973:109, 135

18. ACSC "San Bernardino County," 1941

19. Lindsay 1973b:102

20. Bard 1973:122

21. Federal Writers' Project 1939a:628

22. Lantis 1963:76

23. Lantis 1963:76 
CHAPTER 12. THE 1945-1951 PERIOD: RESIDENTIAL

BOOM ON THE METROPOLITAN FRINGE;

LARGER TOWNS AND INTENSIVE AGRI -

CULTURE GROW WHILE MORE SMALL-

SCALE ACTIVITIES DECLINE.

The postwar period was one of alarming growth in many portions of the California desert. By 1950, desert population figures stood at over 175,000 (see Appendix). Combined with the World War II period growth, population growth during the decade of the 1940s was over 60,000, an increase greater than that which had occurred in the two previous decades combined. Most growth occurred in subdivided areas on the fringe of the metropolitan area, while most of the rest of the desert continued with previous activities or showed declines. Mining experienced little new activity; highway, railroad and other dispersed settlements generally declined. Public enjoyment of the desert boomed, helping to create much higher traffic volumes, and initial interest in off-highway vehicle recreation appeared.

The postwar period in the desert, however, is best known for its city growth and subdivision activity. The growth in the late 1940 s was relatively small in comparison with that occurring in the 1950s and 1960s, but the late 1940s were important because patterns for later decades were established at that time. Growth occurred in four major areas: 1) from Palmdale east and southeast to Apple Valley; 2) in the upper Coachella Valley around Palm Springs; 3) around the northern and western shores of the Salton Sea; and 4) on the high desert between Morongo Valley and Twentynine Palms. ${ }^{1}$ More minor subdivision areas also appeared in extreme 
northeastern Los Angeles County, and in the Borrego Springs area. Specific sites of settlement included Victorville, Desert Springs (Piñon Hills), Palmdale, Pearblossom, Alta Vista, Hi Vista, Yucca Valley, Joshua Tree, Twentynine Palms, Apple Valley, Hesperia, Rancho Mirage, Palm Desert and Borrego Springs. ${ }^{2}$ Most communities had been only crossroad villages before the postwar period, and a few were totally nonexistent. Among the best known of these areas, to the contemporary Los Angeles-area resident at least, was the Tri-Cities area comprising Victorville, Apple Valley, and Hesperia. This area, particularly Apple Valley, was heavily advertised in the Los Angeles area. 3

The boom in postwar desert housing was one of the first large-scale voluntary migrations ever to any desert area. Several reasons were responsible for its attraction. First, urban southern Californians were beginning to feel confined by their metropolitan surroundings; they needed a place for relative solitude. Similarly, they were beginning to appreciate the beauty of the desert and its lack of urban problems - - traffic jams, air pollution, and such. Cheap federal land allowed a wide range of people to settle with a vacation or retirement home, and the availability of air conditioners and swimming pools made it comfortable to live in the desert the year round. ${ }^{4}$

Both year-round residents and Los Angeles-area weekend recreationists lived in the Tri-Cities area, as well as in other areas north of the Transverse Ranges. The same general types of desert resident settled the other areas, with the exception of 
the Palm Springs area. In that area, from Palm Springs southeast to Palm Desert, most residents lived year-round, or at least for most of the non-summer months. Homes were therefore well-constructed and even elegant, and arranged in a close, suburban style.

In other areas, a housing arrangement began to proliferate, known as the "jackrabbit homestead." These dwellings were minimal in size and services, built simply to satisfy the residency requirements laid out in the Federal Small Tracts Act of 1938. 5 First built in 1949, their effect (less than two square miles by 1951) was at first small, but their popularity grew quickly. ${ }^{6}$ They were usually sold in five-acre plots, and with the exception of a graded road to the house site, few other improvements existed except for those supplied by the buyer. Though large areas were put up for sale simultaneously, financing and other problems with dwelling construction created a widely-spaced housing pattern, with only ten to fifty percent of the lots improved. Lots adjacent to the Salton Sea deviated slightly from this pattern. Tracts built close to the water, as a general rule, were normally more substantial and laid out in a more closely-spaced suburban situation, while those further away were typical of "jackrabbit" homesteads in other areas.

Closely connected to the residence and vacation-home boom in the desert was the further growth in desert resort activities. Most of the commercial facilities were located at either the Colorado River or Salton Sea, ${ }^{7}$ and several were operated next to or in conjunction with residential developments. ${ }^{8}$ Enjoyment of 
the desert away from the major paved roads was becoming more commonplace, and with the wartime development of the four-wheel drive Jeep and the air-cooled engine, off-road vehicle (ORV) travel began to occur. 9

While subdivisions and resorts were generally causing demographic statistics and attention to be focused in specific areas of the desert, conditions in much of the rest of the desert were generally stagnating. Even though most highways were receiving more traffic than ever before, the greater speed and dependability of autos caused most people to travel farther between stops. Therefore, only a few new stations were opened up in the postwar years, most being on the more recently completed highway between Indio and Blythe. Several desert way stations closed down. 10

Railroad settlements fared even worse. In the early 1940s, steam locomotives with greatly enlarged boilers came into standard use on the main lines, almost eliminating the need for water stops; ${ }^{11}$ and in the late 1940 s and early 1950s, diesel engines replaced steam as the primary power source. The new engines were almost maintenance-free during their run, thus eliminating water stops entirely. Railroads at this time also began to operate their maintenance-of-way stations from mobile road gangs rather than from fixed trackside facilities. By the late 1940s, then, the number of trackside facilities had been sharply reduced, leaving less than fifty operating stations or maintenance spots along all California desert railroads. ${ }^{12}$ 
Mining, on the whole, became more and more a large-scale enterprise. By and large, it stayed at previous locations, but with the playing out of the iron ore at the Kaiser Vulcan Mine, operations were transferred in 1948 to Eagle Mountain, north of Desert Center. ${ }^{13}$ A company-owned railroad was built to the site soon after, and to facilitate development of this and many smaller mines in that area, Joshua Tree National Monument was reduced to its present size in 1950. 14 Another designated open-space area, Anza Desert State Park, was expanding during the same period, however; it was finally able to patent its lands by 1948 , making a deeded park approximating today's boundaries. 15

Agriculture enjoyed renewed growth during this period. Several new areas were opened for expanded farming use, most important of which was the Coachella Valley south of Indio. The Coachella Canal had been planned for decades prior to the late $1940 \mathrm{~s}$, and construction had begun in the mid-1930s. World War II halted work, however, and the canal was not opened until 1948. 16 Predictably, the canal was a boon to the area. Acreage, which had been previously watered from artesian and deep wells, soon tripled in extent; new acreage was planted in a variety of field crops, as well as citrus, vineyards, and date groves. ${ }^{17}$ The Newberry area opened up to specialized agriculture -- chicken and turkey ranches - - as well as field crops, and the areas around Harper Lake and Borrego Springs, with their efficient pumping and irrigating operations, also expanded at this time. 18 
The military, in general, spent the immediate postwar years converting to peacetime levels. Therefore, Rice Air Base and Blythe Army Base were deactivated. The three supply depots near Barstow converted to Marine Corps jurisdiction soon after the war. ${ }^{19}$ Other areas boomed, however; a parachute test range was developed near El Centro, and a major new base was added in 1947 when the Mojave "B" Range was established southeast of the NOTS facility at China Lake. 20

Finally, grazing became more regulated after the war. The Taylor Grazing Act, passed in 1934, had earlier established the precedent of private leasing of Federal lands, but its implementation had not brought immediate change to former grazing patterns. 21 In 1946, however, stewardship of public lands came under the authority of the Bureau of Land Management. The new organization designated areas for grazing on an annual basis and regulated the number of cattle applicable to the various rainfall and vegetation zones. 


\section{CHAPTER 12 FOOTNOTES}

1. Lantis $1963: 53$

2. ACSC maps, various areas and dates

3. Lantis $1963: 53$

4. Lantis $1963: 53$

5. Bard 1973:112

6. Dana and Krueger 1958:126

7. ACSC maps, various areas and dates

8. Bard 1973:123

9. Lindsay 1973b:104

10. Bard 1973:126

11. Bard 1973:105

12. NRPC 1948

13. Miller 1968:64

14. Rinaldi 1977

15. Lindsay 1973a:258

16. Lantis $1963: 61$

17. Lantis $1973: 72$

18. Lantis 1963:69

19. Bard 1973:108

20. King 1978

21. Bard 1973:111 
112 
CHAPTER 13. THE 1951-1960 PERIOD:

POSTWAR GROWTH TRENDS

CONT INUE; RECREATIONAL

USE OF THE DESERT BE-

COMES MORE NOTICEABLE.

Not remarkably different from the immediate postwar period, the period encompassing the 1950 s basically continued and accentuated previous trends. Specifically, urban and dispersed settlements on the metropolitan margins continued to grow, while highway service clusters found mixed success. The Korean War did provide a definite increase to both military and mining economics for a while, and new mining facilities opened up for cement manufacture in the western desert; otherwise, these economies remained rather static. Resort and off-road vehicle recreation continued their growth trends.

Towns and subdivisions on the metropolitan margin continued to grow. In the $1950 \mathrm{~s}$, fewer new communities were created than before, but the population influx of 150,000 between 1950 and 1960 (see Appendix) was far higher than in any other decade, and almost doubled the total population in the desert. Major areas of influx were the Tri-Cities area around Victorville, Lancaster, Palmdale, Barstow, the Palm Springs area, and the High Desert areas of Morongo Valley, Joshua Tree, Yucca Valley, and Twentynine Palms. Newly subdivided areas created Bell Mountain, California City, Leona Valley, and Salton City; also, many new smaller subdivisions were sprinkled near previously-developed areas. ${ }^{1}$ Because of the speculative nature of many of these semi-rural 
developments, however, large open areas remainded long after subdivision took place, and other areas were only loosely settled.

Because of the overabundance of land, it was inevitable that many ventures failed in their desert development plans. Salton City, a prime example, was an extravagantly planned community on the west side of the Salton Sea, which opened in 1958. Expectations were great; $\$ 10$ million was invested in the project, and streets were laid out for an 11,000-10t development. ${ }^{2}$ Many lots were in fact sold; but, primarily because of the deterioration of Salton Sea water quality, few were built there. Today, a stillstruggling, widely spaced collection of perhaps thirty houses and a few businesses show what became of the dream. Scores of other developments less ambitious in scope have been similarly doomed to failure; located in many parts of the CDCA, they are known only by the bladed roads, tottering street signs, and an occasional marooned house or two.

Resorts and other forms of desert recreation continued to grow, even more rapidly than in the years immediately following the war. Seaside and riverside developments continued to proliferate and expand, capturing a major share of recreation traffic. ${ }^{3}$ Mineral spas, most of which had existed for many years, were located near Tecopa and Blythe, and near the Coachella Canal, east of the Salton Sea. 4

In addition, many new avenues of recreation began to appear. A number of private recreation ponds, interspersed among the newly developed chicken and turkey ranches of the Newberry area, 
were also opened, offering fishing, relaxation, motorcycle riding and other pastimes. ${ }^{5}$ Recreated mining areas appealed to the adventurous at Calico and at Tropico Mine. To the sightseer the Anza-Borrego areas, Joshua Tree and Death Valley were protected areas holding much of the desert's most valuable treasures; though all were established in the 1930s, they did not begin to receive a large number of visitors until the 1950 s (see Figure 4). This also held true for the Lake Mead National Recreation Area; expanded in 1952 with the completion of Davis Dam, it drew far more visitors than any of the California desert parks, and a significant majority of them came from California. ${ }^{6}$ By the $1950 \mathrm{~s}$ there were also several other parks from which to choose. Salton Sea State Recreation Area was established in 1951; Mitchell

Caverns (later Providence Mountains) State Park became a reality in 1956, and Joshua Trees (later Antelope Buttes) State Park was designated in 1957..$^{7}$ None were particularly large, but each protected a valuable part of the desert that had come under the pressures of overuse. A State-administered burro sanctuary, covering much of the Inyo County desert, was also established in 1957 , though its impact on other land uses was negligible. ${ }^{8}$ For four years in the mid-1950s, the Anza-Borrego area operated as two separate entities; Anza Desert State Park was the portion generally south of State Highway 78, while Borrego State Park was the name given to the northern sector. They were reunited into the Anza-Borrego Desert State Park in 1957 and remain so today. Serious proposals were advanced at this time to expand Anza-Borrego 
to the northeast by 52 square miles; however, the plan was never enacted. 9

Other forms of desert travel occurred in less structured areas. Auto touring -- for weekend outings or long distance trips -- became increasingly important, and new roads emanating from Lancaster, Barstow, Trona, and Twentynine Palms were opened to the public. The beginnings of the Interstate freeway system were also seen in the late 1950s. Though the only portions opened by 1960 were those southwest of Barstow, ${ }^{10}$ the completion of the Barstow-Victorville segment was quite significant to the Mojave River communities that it bypassed. A final automobileoriented impact was the off-road recreational vehicle. Its use, and its consequent environmental damage, continued to be fairly light, though its popularity steadily grew.

In other land use alterations, the advent of the Korean War, between 1950 and 1953, provided perhaps the biggest force for change in this period. It caused reactivation of several bases, among them George Air Force Base and Camp Irwin, and also brought about the establishment of the large Marine Corps Training Center near Twentynine Palms in 1952. ${ }^{11}$ In contrast to military activity after World War II, however, the various desert bases stayed in operation after the Korean War. Also during the 1950s, the Salton Sea Base was established, operated by the Atomic Energy Commission and located entirely on the waters of the Salton Sea. ${ }^{12}$

The Korean action also brought about renewed mining interest. Tungsten and manganese were necessary war materials in short 
supply; therefore, small mines in the Anza Desert State Park, Big Maria Mountains and an area north of Barstow were activated, 13 while the Atolia and Darwin areas saw renewed activity.

Unrelated to military needs, the 1950 s saw sharp growth in the cement manufacturing industry. A large cement plant was built at Cushenbury in 1957 near a large limestone deposit, ${ }^{14}$ and a similar operation was built at Creel, west of Mojave, at about the same time. ${ }^{15}$ Exhausting locally-available materials, the cement plant at Victorville had also opened a series of new mining operations by the early 1950s, and a newly-built railroad spur connecting them reached northeast, then east to Sidewinder Mountain. ${ }^{16}$ The Cushenbury and Creel plants were also connected to the main railroad by industrially-owned spurs.

While the vast majority of money in mining was reaped by the large-scale manufacturing concerns, the California desert by this time had come to attract a sizeable number of persons who enjoyed mining, regardless of whether it was particularly profitable. Called "desert rats" and other names by people leading a more conventional life, their ranks were joined by others who, without any particular mining knowledge, so loved the desert that their dependence on conventional human concerns became increasingly tenuous. Their presence in the desert was by no means new; conversely, committed desert lovers (and some persons who were simply antisocial) had lived in remote pockets of the desert for years. 17 However, with the playing out of most of the profitable, single-person mining prospects, the institution of Social 
Security and pension plans, and the increased population and visitor use of the desert, the confirmed "desert rat" came to be viewed differently and became better recognized. A few of these persons -- "Desert Steve" Ragsdale of the Desert Center area, "Burro" Schmidt of the El Paso Mountains, "Death Valley" Scotty and a few with literary inclinations - - have become well-known, but most have intently avoided the general public. Highly individual - occasionally dangerously so - and almost wholly antithetical to governmental processes and interference, they are persons entirely marginal to society who oftentimes live from no economically logical base. They are somewhat ill-defined as a group, but are probably the most basically sensible and colorful of desert characters, and can even today be found in those otherwise empty corners of the desert where one least expects them. 


\section{CHAPTER 13 FOOTNOTES}

1. ACSC maps, various areas and dates

2. Lantis $1963: 70$

3. Lantis 1963:70

Cook 1967:17

4. ACSC maps, various areas and dates

5. Bard 1973:111-112

6. U.S. Department of the Interior, various dates

7. California State Department of Parks and Recreation, various dates

8. Nathensen 1977

9. Lindsay $1973 \mathrm{~b}: 106-108$

10. Bard 1973:115

11. Lantis $1963: 52$

12. ACSC, "Imperial County," date unknown

13. Lindsay $1973 \mathrm{~b}: 108$

Lantis 1963:45

14. Leadabrand $1965: 55$

15. ACSC, "Kern County," 1958

16. Myrick 1962

17. Federal Writers' Project 1939a:521, 544 
CHAPTER 14. THE 1960-1978 PERIOD: CONTINUATION OF GROWTH ON THE METROPOLITAN FRINGE;

FREEWAYS PROLIFERATE; OFF-ROAD

VEHICLE USE BECOMES WIDESPREAD;

DESIGNATED WILDERNESS AREAS APPEAR.

The period since 1960 has been characterized as one of intense use of the desert. With technological progress and the growth of the southern California metropolitan areas, visitors have begun to use the desert to an ever-increasing degree. Previously pristine areas have become roaded, and with the exploding popularity of the four-wheel drive vehicle, even the poorest roads have received some weekend use. In large part, a reaction to the overuse and consequent destruction of some parts of the desert, the most recent period has also become one of increasing governmental regulation: wilderness areas for the ensurement of solitude have been created; off-road vehicle use has been channeled to designated areas; and conflicts over land-use have resulted in government oversight of previously unrestricted desert activities.

As in previous decades, the $1960 \mathrm{~s}$ and early $1970 \mathrm{~s}$ brought many more people to the desert, both to live and visit. The larger desert communities -- Lancaster, Palmdale, the Tri-Cities area, Twentynine Palms, Joshua Tree, Yucca Valley, and Morongo Valley areas, and the cluster of communities around Palm Springs -received the bulk of the new residents. ${ }^{1}$ However, several new communities, in somewhat less accessible locations, were subdivided. Rimrock, Landers, Flamingo Heights, Timico Acres, and 
several tracts east of the Indio Hills were opened up, primarily with loosely clustered "jackrabbit" housing; to the east, a large broken area of similar housing stretched up to twenty miles east of Twentynine Palms. To the west, the Quartz Hill and Lake Los Angeles areas became new subdivisions featuring smaller, suburbanstyle lots. Recreationally-oriented settlements, however, did not limit themselves to the metropolitan fringe; several subdivisions opened up on the west side of Lake Havasu opposite Lake Havasu City, Arizona, and another appeared southwest of Parker. ${ }^{2}$ The Colorado River developments were unique in that they were on Indian Reservations; residents held their land via long-term leases.

Simultaneous with the growth of these new subdivision areas, other subdivisions were beginning to decay. Particularly in those remote areas where the houses were built to minimal specifications and sold at minimum prices, many houses ceased to be lived in after a while and were often not able to be resold. Thus, several subdivisions in the desert eventually became blighted by a high percentage of abandoned, boarded homes, while interspersed among them appeared currently occupied residences, along with a few improved, larger-sized dwellings.

To accommodate the general increase in population, both in the desert and particularly in the coastal areas, many new facilities were built to ease transportation of energy and materials, as well as to facilitate rapid communications. Throughout the $1960 \mathrm{~s}$, the Pacific Telephone and Telegraph Company greatly augmented a 
network of relay stations to facilitate telephone communications; these stations had begun on a small scale as early as 1949 , though their numbers remained small previous to 1960. Though highly visible because of their mountaintop or ridge location and their connecting roads, they occupied less than an acre of ground. They were not permanently occupied; therefore, few adjoining buildings were required. $0 i 1$ and gas pipelines and transmission lines have likewise expanded greatly, chiefly to provide needed energy to the Los Angeles area.

Accessibility to and through the desert, via the freeway, was made markedly easier in this time period. Freeways had begun on the desert in the late 1950 s between Cajon Pass and Barstow. By 1968, however, well over half of the Interstate system had been completed, and by 1973 , it was nearly finished. Also, other freeways were built separate from the Interstate system, such as the Antelope Valley Freeway. By and large, the freeways had a catastrophic effect on wayside highway stops; not only did they speed traffic and make many stops largely inaccessible to the traffic, but in several cases, the freeway was built directly over the highway stop, forcing business owners to relocate or close. Stops well away from the new rights-of-way, such as Helendale and Amboy, withdrew into strictly local business, and many stops largely dependent upon traffic folded up entirely. ${ }^{3}$

Bolstered by the desert's easier accessibility, visitors to the California desert, particularly from the Los Angeles metropolitan area, came in greater numbers than ever before, and to 
help accommodate them, new parks were created around Picacho and Red Rock Canyon. They came seeking a variety of experiences, from dune buggy driving to bird watching, from motorcycle enduros to relaxing in a trailer by the Salton Sea. Off-road vehicle pursuits, in particular, rose dramatically after $1960,{ }^{4}$ and due to its detrimental effects on desert soils, air pollution, plant cover, soil erosion, and other factors, ORV use began to cause consternation among those concerned about desert ecosystems. Furthermore, the increased use of the desert by all recreationists began to cause inevitable disputes over which activities should predominate. To help solve many of these conflicts, the Bureau of Land Management (BLM) began to take a more active role in its stewardship of desert lands.

The BLM organized its desert efforts through the Desert Planning Staff (DPS), an ad hoc organization assembled in the early 1970 s to gather data and coordinate work solely on desert problems. Among its first official decisions, the DPS proposed a plan that would curb indiscriminate ORV use in the more pristine areas of the desert, while designating other areas for specific off-road vehicle use. Called the Interim Critical Management Plan, it was presented to the public in 1973, and is still the primary framework regulating motorized vehicle use in the desert. The functions of the DPS were greatly expanded with the 1976 passage of the Federal Land Management and Policy Act (Organic Act); BLM staff, in conjunction with extensive citizen input, is now engaged in deciding matters on many aspects of desert activity. 
During this most recent period, the desire for designated wilderness areas, as well as open vehicle areas, also came to be increasingly expressed. Though wilderness had begun as a concept unique to the National Forests, the increased use and appreciation of the desert made the concept more widely relevant. The State of California, however, pioneered in the establishment of desert wilderness areas when it designated the Santa Rosa Mountains State Wilderness in 1975 , as one of the first units in the state wilderness system. A much larger wilderness preserve was created the following year when eight separate areas in Joshua Tree National Monument became designated wilderness; and with the passage of the Organic Act in October of the same year, a process was established for designating many of the BLM lands in the California desert as wilderness. 5 Open vehicle areas were also granted, through BLM's "open" designation as well as by the State's Ocotillo Wells vehicle area. Other areas received formal designations as well; for instance, the Pinnacles became a National Historic Landmark in 1967, and other areas were set aside for scientific and research purposes.

Other new impacts were relatively insignificant in comparison to those discussed above. In balance, agriculture changed little; the poultry ranches in the Newberry area declined, ${ }^{6}$ but new areas became irrigated in Fremont Valley, north of California City. ${ }^{7}$ The military changed little in its land use impact on the desert, despite the long struggle in Vietnam. A few new parcels were acquired by the military, chiefly in the Salton Sea area and 
northwest of Barstow, but military parcels were surrendered in the Algodones sand dunes area south and west of Glamis. (Fort Irwin was detactivated by the Army in 1970, but is now administered by the California National Guard). A fairly large area in the California desert was impacted by a large 1964 wargames exercise. Called Project Desert Strike, it extended into Nevada and Arizona, but a majority of it took place on the California side; among the impacted locations was a large area east of Cima, which included much of the Lanfair Valley. ${ }^{8}$ 


\section{CHAPTER 14 FOOTNOTES}

1. U.S. Bureau of the Census 1970

2. ACSC maps, various areas and dates

3. Bard $1973: 115,126$

4. Bard 1973:137-138

5. California State Department of Recreation 1975-76 Rinaldi 1977

6. Bard 1973:135

7. ACSC, "Kern County," various dates

8. Bard 1973:139 
EPILOGUE: PROJECTIONS FOR THE FUTURE

Based upon historical precedent, it can be safely assumed that the California desert is going to experience only increased levels of use in the coming years. Both residential and recreational use of the desert will increase, and other sectors of the economy will experience similar increases.

As in recent years, the primary areas of land use conflict in coming decades will be on the Los Angeles metropolitan fringe. By the year 2000, for instance, the greater Los Angeles and San Diego areas are expected to have a combined population of over fifteen million; this will have resulting impacts on residential and recreational preference, as overcrowding in these areas become increasingly widespread. Therefore, the major desert communities nearest the two metropolitan areas will continue to grow, although at a more steady, less dramatic rate than in the $1940 \mathrm{~s}$ and $1950 \mathrm{~s}$. If recent trends continue, however, several new communities, more distant from the metropolitan apron, may be created. This urban dispersion is due to two factors: first, the continuing popularity of Social Security and pension plans, allowing greater choice of residence; it is also due to the continuing trend of some businesses to locate in areas largely of their own choosing. Many components manufacturers and other high value-added operations can locate independently of traditional transportation and market sites; therefore, it may be expected that some such operations will move to desert areas. 
Agriculture can be expected to stay at fairly stable levels, at least in the near future. Specialized agriculture (primarily truck crops and poultry farming) will continue to migrate to the desert as poultry and milksheds are displaced by urbanization in the Los Angeles basin, though the passage of prime agricultural lands legislation, should it appear in the next few years, would ideally delay this process by eliminating the fallow-lands stage occurring between agricultural productivity and urban-fringe subdivision. Depending on agricultural technology, soils and available water supplies, new field crop (principally alfalfa) areas may be located next to other desert dry lakes, using methods similar to those employed around Harper and Koehn Dry Lakes. Little agricultural land growth is seen in the southern desert, however; the Colorado River's water supply appears to be fully committed, and water tables are too low for economic pumping. The future of mineral production cannot be predicted as easily. While it can be safely assumed that few new significant strikes of precious minerals will occur in the coming years, there will continue to be a large demand for borates, tronarelated chemicals, and rare earths. Based on recent trends, salt will become a less important though continuing desert commodity. Iron and cement will continue their recent production rates in the near future. New deposits, however, are an obvious gray area; with continually changing technology, deposits considered uneconomic today may well be valuable in future years, and care 
should be taken to allow access to needed deposits while amply considering environmental and other factors.

Grazing will probably decline in importance in coming years. Though extensive in its operations, it employs very few people today. Conflicts with other resource users, particularly backcountry desert recreationists, will continue to increase, usually to the ranchers' detriment. Recent environmental regulations that state a reduction in range carrying capacity may further hurt grazing fortunes. In the northwestern desert, grazing and cattledriving will continue into the near future. However, due to low pay and other factors, there is an increasing reluctance on the part of the Basque stockmen to continue their livelihood in the desert; should they leave, it is doubtful that this economic segment would continue in that area.

The military's presence will continue in a fairly static fashion over the next few years. Land uses on the individual reservations, of course, will change as defense requirements permit. Barring an emergency situation, however, no new large areas will come under military jurisdiction in coming years, simply because there are few empty areas left. Smaller areas will be acquired and released from time to time.

The remaining lands - those not already spoken for by other interests - - are going to be largely decided upon in the coming years by the Bureau of Land Management, and by the various citizen groups and individuals who will gather the necessary data and make 
the crucial decisions concerning future land use. Inevitably, some of the remaining land is going to be used for geothermal sites and other energy-related facilities and transportation lines, and these will doubtless take precedence over recreation and most wilderness interests. Some of the land may well be transferred out of BLM jurisdiction, and managed instead by the National Park Service or another public organization. Some will become wilderness areas; with the continuing population influx to southern California, there will be an increased need for wilderness, on alluvial slopes, mesas and playas as well as the more traditional mountainous areas. Finally, there will be new areas for recreation, though due to greater BLM concern in recent years, such areas will probably come under increasing control and regulation because of the harmful effects of overuse on fragile areas. Wilderness areas as well as recreational areas will probably suffer from overuse, though extensive wilderness controls will most likely not be necessary in the near future.

The above predictions have been made largely as the result of the continuation and maturation of present trends. Unknown factors, physical and cultural, will doubtless appear to change the best efforts of planners and private citizens alike; the current legitimacy of various Native claims and demands in other states offers a case in point. Buoyed by recent Native selfawareness, demands for land based upon unratified Indian treaties or reinterpretation of current treaties may well resurface in coming years. Though some cases may be adjudicated with a cash 
settlement, others may involve land transactions, particularly of sacred sites, and population and burial concentrations. 
APPENDIX 


\section{REFERENCES}





\section{REFERENCES CITED}

Adler, Pat and Walt Wheelock, Walker's R.R. Routes 1853 , Glendale, California, La Siesta Press, 1965.

Ainsworth, Ed. Golden Checkerboard, Palm Desert, Desert-Southwest, Inc., 1965.

Aleshire, Peter, "Bob Hillery Loves His Town," (Palm Springs), Desert Sun, November $7,1977, \mathrm{p} . \mathrm{D}-7$.

Aleshire, Peter, "Early Rancho Mirage...01d-Time Residents Remember," Palm Springs Desert Sun, November 7, 1977, p. F-1.

AAUW - American Association of University Women (Inyokern Branch), Indian Wells Valley Handbook, (2nd ed.), China Lake, 1953.

Aschmann, Homer, "The Head of the Colorado Delta," reprint from Geography as Human Ecology, London, Edward Arnold, n.d.

ACSC - Automobile Club of Southern California, various County, State and highway strip maps, 1917 to 1978.

Bancroft, Hubert H., History of California, Volume II (1801-1824), from The Works of Hubert Howe Bancroft, Volume XIX, San Francisco, The History Company, 1886.

Bancroft, Hubert H., History of California, Volume III (1825-1840), from The Works of Hubert Howe Bancroft, Volume XX, San Francisco, The History Company, 1886.

Bard, Robert Charles, Settlement Pattern of the Eastern Mojave Desert, Fh.D. Dissertation, University of California at Los Angeles, 1973.

Baxter, Don J., Gateways to California, San Francisco, Pacific Gas \& Electric, 1968.

Bean, Lowell John and William M. Mason, "Diaries and Accounts of the Romero Expeditions in Arizona and California, 1823-1826," Ward Ritchie Press, Los Angeles, 1962.

Beattie, George W., "Development of Travel Between Southern Arizona and Los Angeles As It Related to the San Bernardino Valley," Historical Society of Southern California Annual Publications, 13(1924), part II, pp. 228-257.

Beck, Warren A. and Ynez D. Haase, Historical Atlas of California, Norman, Oklahoma, University of Oklahoma Press, 1974. 
Belden, L. Burr, "Forgotten Army Forts of the Mojave," Los Angeles Corral of the Westerners, Brand Book Number 11 (1964), pp. $85-104$.

Bell, Major Horace, On the old West Coast, edited by Lanier Bartlett, New York, Grossett \& Dunlap, 1930.

Bell, James G., "Log of the Texas-California Cattle Trail, 1854," Southwestern Historical Quarterly, reprint, edited by J. Evetts Haley, 1932.

Blake, William P., "Geological Report." In: "Routes of Explorations in California For Railroad Routes to Connect with Routes Near the 35 th and 32 nd Parallels of North Latitude." Compiled by Lt. R.S. Williamson in the Corps of Topographical Engineers, Volume $V$ of Reports of Exploration and Surveys to Ascertain the Most Practicable and Economical Route For a Railroad From the Mississippi River to the Pacific Ocean, Made Under the Direction of the Secretary of War in 1853-1855. Beverley Tucker, Washington, 1856.

Bolton, Herbert Eugene, Anza's California Expedition, Volumes I and II, University of California Press, Berkeley, California, 1930 .

Burns, Lynn, "Homesteaders Found Water," (Palm Springs) Desert Sun, November 7,1977, P. D-3.

Cadwallader, General Sylvanus, "My Trip to the Desert (1892)," San Diego Corral of the Westerners, Wrangler (June 1975), pp. $1-10$.

California Department of Parks and Recreation, Annual Report, various issues, 1964 to 1977.

Carter, William F., Ghost Towns of the West, Menlo Park, Lane Publishing Company, 1971.

Casebier, Dennis G., Tales of the Mojave Road No. 5, Norco, California, Tales of the Mojave Road Publishing Company, 1975.

Chase, J. Smeaton, Our Araby: Palm Springs and the Garden of the Sun, Pasadena Star-News Publishing Company, 1920.

Conner, Leon, Operations Branch, Real Estate Division, Naval Facilities Engineering Command, Department of the Navy, personal communication, February 1, 1978.

Cook, Fred S., "Case of the Missing Bedroll, The," California Traveler 22 (November, 1967a), pp. 7-12. 
Cook, Fred S., "Down by the River Colorado," California Travezer 22 (November, 1967b), pp. 15-17.

Cook, Fred S., "Needles Was Built by a Railroad," California Traveler 22 (November, 1967c), pp. 21-27.

Cook, Fred S., "Tale of Twenty-Nine Palms, A," California Traveler 22 (November, 1967d), pp. 18-19.

Dana, Samuel Trask and Myron Krueger, California Lands; Ownership, Use and Management, Washington, American Forestry Association, 1958.

Davis, James T., "Trade Routes and Economic Exchange Among the Indians of California," Balzena Press Publications in Archaeology Ethnology and History No. 3, Ramona, California, 1974. (Reprinted from University of California Archaeological Survey Report No. 54. Berkeley, California, 1961).

Dekens, Camiel, Riverman Desertman (as told to Tom Patterson), Riverside, Press Enterprise, 1962.

Drucker, P., "Culture Element Distributions: XVII Yuman-Piman," University of California Archaeological Reports No. 6, Berkeley, California, 1941, pp. 91-230.

Dunke, Glenn, The Boom of the Eighties in Southern California, San Marino, Huntington Library, 1944.

Edwards, E. I., The Enduring Desert, Los Angeles, Ward Ritchie Press, 1969.

Edwards, E. I., "Freeman's, A Stage Stop on the Mohave," Glendale, California, La Siesta Press, 1964.

Ernst, Paul, "Discussion of Fluctuations in Rangeland, Use on the California Desert," Riverside, California, Bureau of Land Management, unpublished manuscripts, 1977.

Evans, James Rittenhouse, Diary, 1923, manuscripts.

Ezell, Paul H. and Greta S., "Background to Battle: Circumstances Relating to Death on the Gila, 1857," Trooper West, Frontier Heritage Press, 1970, pp. 168-187.

Ezel1, Paul H., "The Cocomaricopa Mail," Brand Book No. 1, The San Diego Corral of the Westerners, 1968, pp. 28-34.

Farnsworth, Harriett, Remnants of the old West, San Antonio, Naylor Company, 1965. 
Federal Writers' Project, California (Works Progress Administration), New York, Hastings House, 1939a.

Federal Writers' Project, Death Valzey: A Guide (Works Progress Administration), Boston, Houghton Mifflin Company, $1939 \mathrm{~b}$.

Fletcher, Colin, The Thousand Mize Summer, Berkeley, California, Howe11-North, 1964.

Ford, Walter, "Old Death Valley Trails," Desert 38 (November, 1975), pp. $38-40$.

Ford, Walter, "Power from the Wind," Desert 38 (June, 1975), pp. $22-23$.

Forde, C. D., "Ethnography of the Yuman Indians," University of California Publications in American Archaeology and Ethnography No. 28, pp. 83-278.

Friedman, Richard L., Public Information Officer, California Department of Transportation, Sacramento, personal communication, March 2, 1978.

Garrison, Jeanne, "Barstow, California, A Transportation Focus in a Desert Environment," Economic Geography 29 (April, 1953), pp. $159-167$.

Gifford, Edward W., "The Kamia of Imperial Valley," Bureau of American Ethnology BuzZetin No. 97, Smithsonian Institute, Washington, D.C., 1931.

Goulding, James E., "The Founding of a Mojave Desert Community," California Historical Society Quarterly 27 (June, 1948), pp. 113-129.

Gudde, Erwin, California Place Names, University of California Press, Berkeley, California, 1949.

Guinn, J. M., "The Real Estate Boom of 1887," Historical Society of Southern California Annual Publications, 1890, pp. 13-21.

Hafen, LeRoy R., and Ann W. Hafen (eds.), ozd Spanish Traiz: Santa Fe to Los Angeles, Volume 1, in The Far West and the Rockies Historical Series: 1820-1875, Glendale, California, The Arthur H. Clark Company, 1954.

Hanson, J. W., The American Italy: Southern California, Chicago, W. B. Conkey, 1896. 
Harris, Benjamin Butler, The Gila Trail; The Texas Argonauts and The California Gold Rush, Norman, Oklahoma, University of Oklahoma Press, 1960.

Hayes, Benjamin, Pioneer Notes of Judge Benjamin Hayes, private printing, Los Angeles, California, 1929.

Heizer, Robert F., The Eighteen Unratified Treaties of 1851-1852 Between the California Indians and the United States Government, Archaeological Research Facility, University of California, Berkeley, California, 1972 .

Heizer, Robert F. and Adam Treganza, Mines and Quarries of the Indians of California, Reports of the State Mineralogist $40:(3)$, State of California, Department of Natural Resources.

Henderson, Tracy, Imperial Valley, Calipatria, privately printed, 1978 .

Huggins, Robert A., Public Information Officer, Lake Mead National Recreation Area, National Park Service, personal communication, February 3, 1978.

Hussar, John, "Railroads Led the Way," (Palm Springs) Desert Sun, November 7,1977, p. E- 2 .

James, George Wharton, The Wonders of the Colorado Desert, Boston, Little, Brown and Company, 1911.

Johnston, Philip, "Derelicts of the Colorado Desert," Touring Topies 4 (February, 1928), pp. 18 and 37.

Johnston, Philip, "Great Cat of the Desert," Westways 16 (October, $1940)$, pp. 12-13.

Kelsey, Harry, "The California Indian Treaty Myth," Southern California Quarterly, Fal1 1973, 55:229-230.

Ketcham, Walter E., "Sketch of Twenty Nine Palms," Twenty Nine Palms Desert Traiz, June 7, 1935, pp. unknown.

King, Chester and Dennis G. Casebier, "Background to Historic and Prehistoric Resources of the East Mojave Desert Region," Bureau of Land Management, Desert Planning linit, Riverside, California, 1976.

King, Loretta, Public Information Office, China Lake Naval Weapons Center, personal communication, March 9, 1978.

Kroeber, Alfred E., Handbook of the Indians of California, Berkeley, California Book Company, 1970. 
Kruttschnitt, T. J., Vice President, Southern Pacific Transportation Company, personal communications, January 25, 1978 and March 14, 1978.

Laird, Carobeth, The Chemehuevi, Banning, California, Malki Museum, 1976.

Lantis, David W., Rodney Steiner and Arthur E. Karinen, California; Land of Contrast, Belmont, California, Wadsworth Publishing Company, 1963.

Leadabrand, Russ, Exploring California Byways, Volume VI: Owens Valley - - Trips for a Day or a Weekend, Los Angeles, Ward Ritchie Press, 1972.

Leadabrand, Russ, Exploring California Byways, Volume III: Desert Country, Los Angeles, Ward Ritchie Press, 1969.

Leadabrand, Russ, Guidebook to the Mojave Desert of California, Los Angeles, Ward Ritchie Press, 1966.

Leadabrand, Russ, Guidebook to the San Bernardino Mountains of California, Los Angeles, Ward Ritchie Press, 1965.

Leadabrand, Russ, Guidebook to the San Gabriel Mountains of California, Los Angeles, Ward Ritchie Press, 1964.

Leadabrand, Russ, "Kelso Valley and Jawbone Canyon," Westways 43, February 1967, pp. 20-22.

Lucas, Thomas, personal communication, San Diego, California, 1976. Oral interview is on file with the San Diego Historical Society.

Lindsay, Diana Elaine, "Anza-Borrego Desert: The Story of the Nation's Largest State Park," unpublished M.A. Thesis, San Diego State University, 1973 a.

Lindsay, Diana Elaine, Our Historic Desert, San Diego, Copley Books, 1973b.

Littlepage, Arthur M., "Desert Vagabonds," 1908 manuscript.

Lowe, Deke, "California's Last Frontier Playground," Desert 38 (April, 1975), pp. 24-27.

Meller, Sidney L., The Desert Training Center and C-AMA: Study No. 15, Washington, D.C., Army Ground Forces, Historical Section, 1946.

Miller, Ronald Dean, Mines of the High Desert, Glendale, La Siesta Press, 1968. 
Miller, Ronald Dean, Mines of the Mojave, Glendale, La Siesta Press, 1976.

Mojave River Valley Museum Association, Once Upon a Desert; a Bicentennial Project, Patricia Jernigan Keeling, ed., Barstow, California, The Association, 1977.

Morain, Stanley A., "The Changing Pattern of Federally-Administered Land in Riverside County, California," unpublished B.A. Thesis, University of California at Riverside, 1963.

Murbarger, Ne11, "The Ghost Towns of Inyo," Los Angeles Corral of the Westerners, Brand Book Number 11, 1964, pp. 1-18.

Myrick, David F., Railroads of Arizona; Volume I, the Roads of Southern Arizona, Berkeley, Howell-North Books, 1975.

Myrick, David F., Railroads of Nevada and Eastern California; Volume II, Eastern California, Berkeley, Howell-North Books, 1962 .

Nadeau, Remi, "King of the Desert Freighters," Los Angeles Corral of the Westerns, Brand Book Number 11, 1964, pp. $151-170$.

Nathenson, Simon, Fish and Wildlife Resources, Department of Fish and Game, personal communications, December 8, 1977 and April 7, 1978.

NRPC - National Railway Publishing Company, Official Guide to the Railroads, Issues of May 1911, August 1929, October 1939, March 1943, October 1948, and June 1964.

Neal, Howard, "Death Valley Charcoal Kilns," Desert 38 (November, 1975), pp. 14-15.

O'Dell, Scott, Country of the Sun, New York, Thomas Y. Crowell \& Son, 1957.

O'Neal, Lulu Rasmussen, A Peculiar Piece of Desert, Los Angeles, Westernlore Press, 1957.

Otis, David, Guideposts to History, San Bernardino Santa Fe Savings \& Loan Association, 1977.

Paher, Stanley, Death Valzey Ghost Towns, Las Vegas, Nevada Publications, 1973.

Parker, Horace, Anza-Borrego Desert Guide Book, Balboa Island, Paisano Press, 1957.

Pearce, Al, "When Man First Set Foot on Valley Sands," (Palm Springs) Desert Sun, November 7, 1977, p. D-1. 
Peddy, J.E., District Director, California Department of Transportation, San Bernardino, personal communication, February 8 , 1978 .

Pepper, Choral, A Guidebook to the Colorado Desert of California Los Angeles, Ward Ritchie Press, 1972.

Pourade, Richard, ed., The History of San Diego; Volume I, The Explorers, San Diego, Union-Tribune Publishing Company, 1960.

Preston, R.N., Early California [maps], Corvallis, Oregon, Western Guide Publịshers, 1974.

Rand McNally and Company, Business Atlas and Shippers' Guide, Chicago, Rand McNaliy, various dates between 1877 and 1918 .

Rinaldi, Charles R., Chief, Land Acquisition Division, National Park Service, Department of the Interior, personal communication, January 9, 1978.

Roske, Ralph, Everyman's Eden; A History of California, New York, Macmillan Company, 1968.

"Saga of Indian Wells, The," (Palm Springs) Desert Sun, November 7, 1977 , p. D-6.

Sample, L.L., "Trade Routes in Aboriginal California," University of California Archaeological Survey Reports No. 8, Berkeley, California, 1950.

Schroeder, Alfred, A Brief Survey of the Lower Colorado River From Davis Dam to the International Border, National Park Services, Santa Fe, New Mexico, 1952.

Settle, Glen A. (compiled by), Here Roamed the Antelope, Rosamond, California, Kern-Antelope Historical Society, 1963.

Spears, John R., IZlustrated Sketches of Death Valley and other Borax Deserts of the Pacific Coast, Chicago, Rand McNally and Company, 1892 .

Spier, Leslie, Yuman Tribes of the Giza River, University of Chicago Press, Chicago, 1933.

Starry, Robert Martin, Exploring the Ghost Town Desert, Los Angeles, Ward Ritchie Press, 1973.

Steere, Collis H., Imperial and Coachelza Valzeys, Stanford, Stanford University Press, 1952. 
Strong, Mary Frances, "Amargosa Gorge," Desert 38 (November, 1975a), pp. $20-23$.

Strong, Mary Frances, "Little Fenner Valley," Desert 38 (August, 1975 b), pp. 8-9.

Strong, Mary Frances, "Bedrock Canyon and Beyond," Desert 39 (April, 1976), pp. 28-31.

Strong, Mary Frances, Desert Gem Traizs, Mentone Gem Books, California, 1971.

Treolar, Richard, "Mojave's Desert Queen," Desert 38 (December, 1975), pp. 36-37.

Turner, George, Slim Rails Through the Sand, Los Angeles, TransAnglo Books, 1964.

Turner, Justin, G., "The First Letter From Palm Springs," The Historical Society of Southern California Quarterly 61 (Summer, 1974), pp. 123-124.

U.S. Bureau of the Census, Department of Commerce, U.S. Census of Population; Number of Inhabitants, censuses of 1860 through 1970 .

U.S. Department of the Interior, National Park Service, Statistical Division, Public Use of the National Parks; a Statistical Report, Volumes of 1904-40,1941-53,1954-64,1960-70.

U.S. Department of the Interior, National Park Service, Statistical Division, Public Use of the National Park System; Calendar Year Report, Issues of 1972, 1974, 1976, 1977.

U.S. Post Office Department, Postmaster, Appointment Registers, 1865-present, compiled irid distributed by Alan Patera.

United States Geological Survey Quadrangles, various dates and scales.

Ver Planck, William E., Gypsum in California, State of California, Department of Natural Resources, Division of Mines, Bulletin 98 , 1952 .

Ver Planck, William E., Salt in California, State of California, Department of Natural Resources, Division of Mines, Bulletin 175, March, 1958.

Wallace, Mona, "She Sees Thousand Palms Changes," (Palm Springs) Desert Sun, November 7, 1977, p. F-6. 
Warren, Elizabeth Von Till and Ralph J. Roske, "Cultural Resources of the California Desert, 1776-1880: Historic Trails and Wagon Roads," Bureau of Land Management, Desert Planning Unit, Riverside, California, 1978.

Weide, Margaret and James P. Barker, Background to Prehistory of the Yuha Desert Region, United States Department of Interior, Bureau of Land Management, Riverside, California, 1974.

Weight, Harold $0 .$, "Leadfield Died of Complications," Desert 40 (November, 1977), p. 34 .

Weymouth, F.E., The Colorado River Aqueduct, Los Angeles, Metropolitan Water District of Southern California, 1939.

Wilke, Philip J. and Harry W. Lawton, "Early Observations on the Cultural Geography of Coachella Valley." In; "The Cahuilla Indians of the Colorado Desert: Ethnohistory and Prehistory," (ed.) Lowell J. Bean, Ballena Press Anthropological Paper No. 3, Ramona, California, 1975.

Wynn, Marcia Rittenhouse, Desert Bonanza: The Story of Early Randsburg, Glendale, California, Arthur H. Clark Company, 1963. 



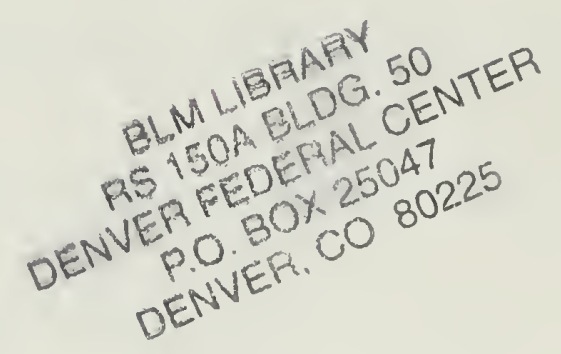




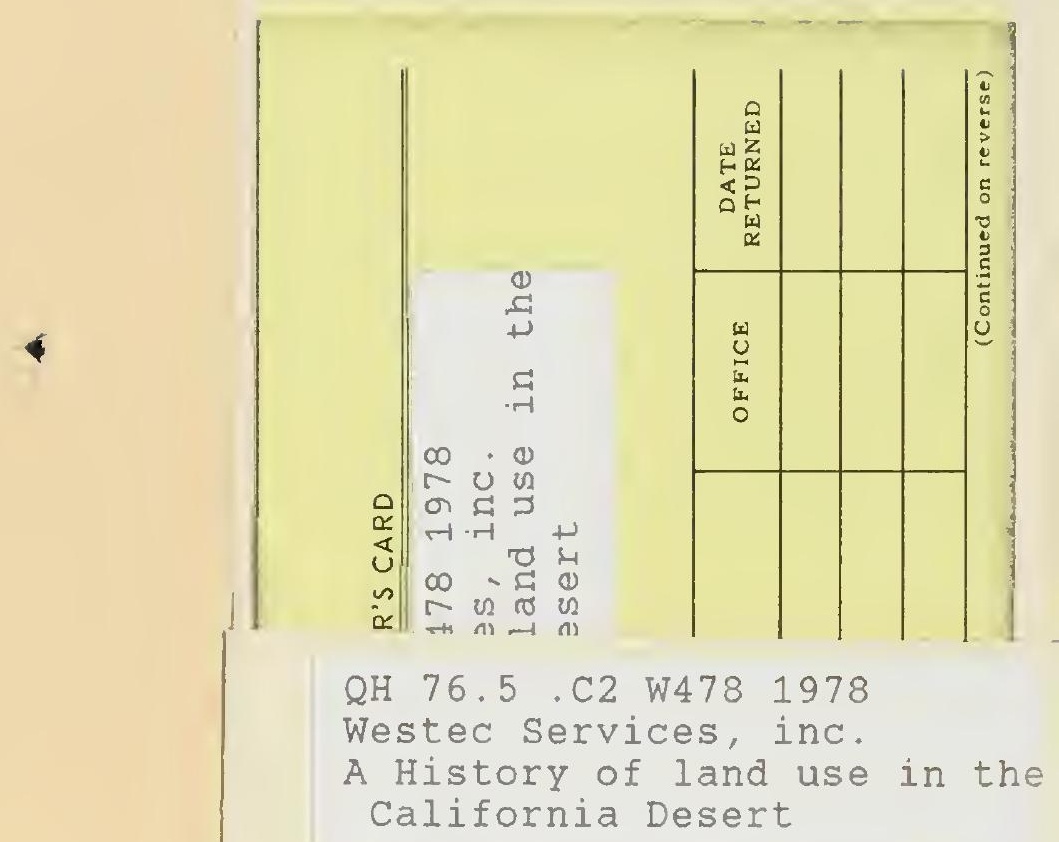

BLM LIBAARY

RS 150A BLDG. 50

DENVER FEDERAL CENTER

P.O. BOX 25047

DENVER, CO 80225 
